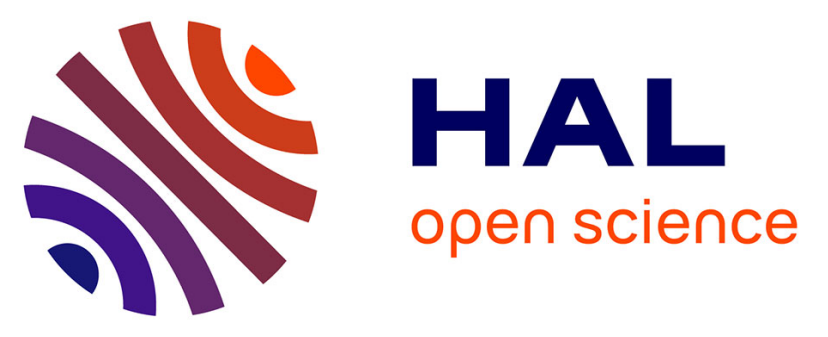

\title{
Paleohydrological and paleoenvironmental changes recorded in terrestrial sediments of the Paleocene-Eocene boundary (Normandy, France)
}

Sylvain Garel, Johann Schnyder, Jérémy Jacob, Christian Dupuis, Mohammed Boussafir, Claude Le Milbeau, Jean-Yves Storme, Alina I. Iakovleva, Johan Yans, François Baudin, et al.

\section{To cite this version:}

Sylvain Garel, Johann Schnyder, Jérémy Jacob, Christian Dupuis, Mohammed Boussafir, et al.. Paleohydrological and paleoenvironmental changes recorded in terrestrial sediments of the PaleoceneEocene boundary (Normandy, France). Palaeogeography, Palaeoclimatology, Palaeoecology, 2013, 376, pp.184-199. 10.1016/j.palaeo.2013.02.035 . insu-00801796

\section{HAL Id: insu-00801796 \\ https://hal-insu.archives-ouvertes.fr/insu-00801796}

Submitted on 18 Mar 2013

HAL is a multi-disciplinary open access archive for the deposit and dissemination of scientific research documents, whether they are published or not. The documents may come from teaching and research institutions in France or abroad, or from public or private research centers.
L'archive ouverte pluridisciplinaire HAL, est destinée au dépôt et à la diffusion de documents scientifiques de niveau recherche, publiés ou non, émanant des établissements d'enseignement et de recherche français ou étrangers, des laboratoires publics ou privés. 


\section{Paleohydrological and paleoenvironmental changes recorded in terrestrial sediments of the Paleocene-Eocene boundary (Normandy, France)}

Authors: Sylvain GAREL ${ }^{\text {a, b, c, d, e }}$, Johann SCHNYDER $^{a}$, Jérémy JACOB ${ }^{\text {b, c, d }}$, Christian DUPUIS ${ }^{\dagger}$, Mohammed BOUSSAFIR ${ }^{b, c, d}$, Claude LE MILBEAU ${ }^{b, c, d}$, Jean-Yves STORME ${ }^{g}$, Alina I. IAKOVLEVA ${ }^{\mathrm{h}}$, Johan YANS ${ }^{\mathrm{g}}$, François BAUDIN ${ }^{\mathrm{a}}$, Christine FLÉHOC ${ }^{\mathrm{i}}$, and Florence QUESNEL ${ }^{\text {d, e }}$

a UPMC Université Paris 06/CNRS, UMR 7193 ISTeP, 4 place Jussieu, 75005 Paris, France.

b Université d'Orléans, ISTO, UMR 7327, 45071, Orléans, France.

${ }^{\mathrm{c}}$ CNRS/INSU, ISTO, UMR 7327, 45071 Orléans, France.

dBRGM, ISTO, UMR 7327, BP 36009, 45060 Orléans, France.

e BRGM GéoRessources/GAT, 45060 Orleans Cedex 2, France

${ }^{\dagger}$ Laboratoire de Géologie Fondamentale et Appliquée, Faculté Polytechnique de Mons, Université de Mons, rue de Houdain 9, B-7000 Mons, Belgium.

${ }^{\mathrm{g}}$ FUNDP, Namur, Department of Geology, 61 rue de Bruxelles, 5000 Namur, Belgium.

${ }^{\mathrm{h}}$ Geological Institute, Russian Academy of Sciences, 109017 Moscow, Russia.

i BRGM LAB/ISO, 45060 Orleans Cedex 2, France

Correspondence: Sylvain Garel, Université Pierre et Marie Curie, UMR 7193 ISTeP, 4 place Jussieu Tour 56-66 5ème étage, 75005 Paris, France. Tel. 33 144274786; e-mail: sylvain.garel@upmc.fr 


\section{Abstract}

The Paleocene-Eocene boundary (55.8 Ma) is associated with the Paleocene-Eocene Thermal Maximum (PETM), which is characterized by a negative Carbon Isotope Excursion $(\mathrm{CIE})$, reflecting a major perturbation of the carbon cycle, and by an extreme and rapid global warming. The Cap d'Ailly area (Upper Normandy, France), in which previous studies have revealed the Paleocene-Eocene transition, is a reference locality for organic-rich terrestrial and lagoonal deposits of the "Sparnacian" stage, widespread in Northwestern Europe. In this study, we focus on the organic matter content of the Vasterival section. Organic data (RockEval, palynofacies, biomarker analyses and compound specific isotope analyses) were acquired in order to constrain the paleoenvironmental and paleohydrological changes that occurred at the Paleocene-Eocene boundary. Stable carbon isotope compositions of higher plant leaf wax $n$-alkanes reveal a CIE of $-4.5 \%$, extending throughout the second half of the studied section. Palynofacies observations reveal: (i) an abrupt shift from a closed, quiescent marsh pond to an open eutrophic swamp subjected to algal blooms, concomitant with the onset of the CIE; and (ii) the evolution from a swamp to a tidal flat due to the marine transgression that occurred during the PETM. Higher plant biomarkers and their hydrogen isotopic composition compared to nitrogen analyses suggest: (i) dry episodes just before the PETM that may help to understand the triggering of this hyperthermal event; (ii) a moister climate associated with a stronger seasonality during the early PETM.

Keywords: Paleoenvironments; Paleohydrology; Continental ecosystems; Hydrogen isotopes; Carbon isotopes; Dieppe-Hampshire Basin; PETM 


\section{Introduction}

The Paleocene-Eocene Thermal Maximum (PETM), one of the most abrupt climatic events of the Cenozoic, was a period of extreme $\left(4-8^{\circ} \mathrm{C}\right)$ and short-lived $(160-210 \mathrm{kyr})$ warming that had significant consequences on marine and terrestrial environments (e.g. Kennett and Stott, 1991; Koch et al., 1992; Zachos et al., 2003; Sluijs et al., 2006; Röhl et al. 2007; Westerhold et al., 2008; Murphy et al., 2010; Mclnerney and Wing, 2011). In the marine realm, the PETM is associated with a rise in sea surface temperatures of up to $8^{\circ} \mathrm{C}$ (Kennett and Stott, 1991; Zachos et al., 2001), global proliferation of subtropical dinoflagellates Apectodinium (Bujak and Brinkhuis, 1998; Crouch et al., 2003; Aubry et al., 2007), a mass extinction of benthic foraminifera (Kennett and Stott, 1991), and deep ocean acidification (Zachos et al., 2005). On land, it coincides with a change in plant community pattern (Wing et al., 2005), the appearance of modern mammalian orders (Gingerich 1989, 2006), and intercontinental mammal migrations (Smith et al., 2006).

The PETM is further characterized by a global and abrupt drop (-2.5 to $-6 \%$ ) in $\delta^{13} \mathrm{C}$ values followed by a gradual recovery to initial values (Kennett and Stott, 1991; Aubry et al., 2007; McInerney and Wing, 2011; Storme et al., 2012a). This Carbon Isotope Excursion (CIE) is recorded in both marine and terrestrial sediments (Koch et al., 1992; Thiry and Dupuis, 1998; Zachos et al., 2001; Magioncalda et al., 2004; Aubry et al., 2007) and seems to be the result of a rapid and massive injection of isotopically light carbon into the ocean-atmosphere system (Kennett and Stott, 1991). Several sources have been suggested for this light carbon, such as methane clathrates (Dickens et al., 1995; 1997), organic matter desiccation and oxidation due to the uplift of epicontinental seas (Gavrilov et al., 1997; Higgins and Schrag, 2006), injection of basaltic sills into organic-rich sediments (Svensen et al., 2004, 2010), and burning of large peatlands (Moore and Kurtz, 2008).

Only a few PETM terrestrial sections have been studied until now. The most famous sections are located in the Bighorn Basin (Wyoming) and have been investigated by paleontological (Gingerich, 1989, 2006; Wing et al., 2005), isotopic (Koch et al., 1992; Magioncalda et al., 
2004; Yans et al., 2006), molecular (Smith et al., 2007), and sedimentological studies (Koch et al., 1992; Magioncalda et al., 2004; Kraus and Riggins, 2007; Smith et al. 2008). To our knowledge, this is the only example of basin scale multi analyses of the impact of the PETM in terrestrial settings. This scarcity of regional and multidisciplinary studies in terrestrial environments hampers our understanding of the regional consequences of such a global climatic crisis.

In Northwestern Europe, Lower Paleogene terrestrial to lagoonal successions are recognized in the Paris and in the Dieppe-Hampshire Basins, among others. These deposits belong to the "Sparnacian" stage and are well known for their high content in organic matter (OM; Aubry et al., 2005). In the easternmost part of the Dieppe-Hampshire Basin, several Paleocene/Eocene (P-E) sections are scattered along the cliffs of the "Côte d'Albâtre" (Upper Normandy; Fig. 1). These outcrops are well exposed, are continuously renewed by erosion and exhibit sediments with well-preserved OM. Furthermore, their central location with respect to the sub-basins of the North Sea Basin makes them reference sections for northwestern European terrestrial-shallow marine P-E deposits (Magioncalda et al., 2001; Aubry et al., 2005; Smith et al., 2011; Storme et al., 2012b).

In this paper, we present a multi-proxy study of the OM from the Vasterival locality, a key section of the Dieppe-Hampshire Basin in which the CIE onset has already been described (Sinha, 1997; Thiry and Dupuis, 1998; Magioncalda et al., 2001; Storme et al., 2012b). $n$-alkane $\delta^{13} \mathrm{C}$ was used to constrain the extent of the CIE. Palynofacies observations provided data on the high-scale evolution of the depositional environment during the beginning of the PETM. The relative abundances of $n$-alkanes allowed evaluation of changes in vegetation composition. Paleohydrological changes were constrained by $n$-alkane $\delta \mathrm{D}$, substantiated by the $\delta \mathrm{D}$ of onocerane I, an unusual higher plant biomarker (Pearson and Obaje, 1999; Jacob et al., 2004). These results were then compared to climatic changes observed in PETM sites of low (Handley et al., 2012), mid (Secord et al., 2010; Handley et al., 2011) and high latitudes (Pagani et al., 2006). Moreover, the timing of these changes was 
compared to that of the CIE in order to determine whether climatic and environmental changes preceded or followed the mass injection of greenhouse gases into the oceanatmosphere system, Finally, all the integrated data reported here unravel how a mid-latitudeswamp-environment responded to a global climate change.

\section{Site description}

The Vasterival section is located along the "Côte d'Albâtre", a few kilometers west of Dieppe (Fig. 1). It is a $2 \mathrm{~m}$ thick section that encompasses the lignite complex (L1) of the composite section of the Cap d'Ailly area (Fig. 2). The L1 is part of the "Sparnacian" Mortemer Formation (Dupuis and Steurbaut, 1987; Dupuis et al., 1998; Magioncalda et al., 2001; Aubry et al., 2005), which comprises (from the bottom to the top): fluvial sands and sandstones ("Sables et Grès du Pays de Caux" Member, SP1; Fig. 2), lacustrine limestones and marls of the Peckichara disermas charophyte zone, paleosols and the 1m-thick L1 ("Calcaires, marnes et lignites (L1) du Cap d'Ailly" Member, SP2; Fig. 2) that contains a freshwater association of mollusks rich in Unio wateleti (Bignot, 1965; Dupuis et al., 1998; Magioncalda et al., 2001). The "Sables et Argiles à Ostracodes et Mollusques" Member (SAOM), belonging to the Soissonnais Formation (SP3 and SP4), is locally delimited from the L1 by an erosive base (Fig. 2). These brackish-marine deposits are composed of an alternation of sands, silts and clays with variable amounts of mollusk shells forming regular coquina beds (Dupuis et al., 1998). The lower part of this member crops out in the Vasterival section (Fig. $3)$.

The Vasterival outcrop is ca. $2 \mathrm{~m}$ high and is continuously refreshed by a stream of water. In this section, the lignite complex L1 comprises a succession of five multicentimeter-scale lignite beds (Lb1 to Lb5), interstratified within more or less OM-rich silt and clay beds (Fig. 3). Three clay beds exhibit root traces (levels Rb1 to Rb3; Fig. 3), and the other two present carbonate nodules of up to $15 \mathrm{~cm}$ in length (levels $\mathrm{Nb} 1$ and Nb2; Fig. 3). The other clay beds are labeled $\mathrm{Cb} 1$ to $\mathrm{Cb} 3$. Unio shells are reported between $60 \mathrm{~cm}$ and $1 \mathrm{~m}$ above the base of 
the section. Recently, Storme et al. (2012b) confirmed the presence of the CIE onset in Vasterival, which begins at $98 \mathrm{~cm}$ (Fig. 3).

Before sampling operations, the outcrop was refreshed by removing the superficial layer ( 5 to $10 \mathrm{~cm}$ ) with shovel and spade. A continuous sampling of the section was obtained by collecting a series of blocks (10 cm-high and $5 \mathrm{~cm}$-thick). Each sample was then carefully placed in aluminum foil immediately after being collected. Before analyses, the outer rim (0.5 to $1 \mathrm{~cm}$ ) of every sample was removed in order to minimize contamination.

\section{Methods}

\subsection{Palynofacies analyses}

30 samples were crushed, oven dried and treated with $\mathrm{HCl}$ and $\mathrm{HF}$ to remove the mineral matrix. In order to have the most representative views of the total OM, no other treatments were performed for palynofacies observations. These observations carried out with an Axioplan2 Imaging Zeiss microscope under transmitted light and under UV excitation (Zeiss HBO 100 Microscope Illuminating System, mercury short-arc lamp). Over 2000 surface units per sample were counted to estimate the relative proportion of each organic fraction. The counting was considered to be relevant for a counting surface that corresponds to at least 500 counted particles per sample. Three main groups of particles were discriminated. A palynomaceral group is composed of phytoclasts. It is subdivided into brown wood, cuticles, black phytoclasts and charcoal (see Batten, 1996) and gelified phytoclasts (Fig. 4). The palynomorph group comprises freshwater algae Pediastrum and Botryococcus, dinoflagellates and spores and pollen grains. The Amorphous Organic Matter (AOM) group is subdivided into fluorescent AOM (fAOM), diffuse AOM (dAOM), and gelified AOM (Fig. 4). As gelified amorphous organic matter is likely to correspond to degraded gelified phytoclasts 
(Tyson, 1995), gelified phytoclasts plus gelified AOM will be further referred to as gelified OM.

\subsection{Bulk and molecular organic geochemistry}

\subsubsection{Bulk organic analyses}

32 samples were analyzed with a Leco automatic carbon determinator (IR-212) that gives more reliable TOC values, for samples displaying high amounts of terrestrial OM, than those obtained by Rock-Eval analyses (Espitalié et al., 1985b).

Depending on the OM content, between 50 and $100 \mathrm{mg}$ of dried sediments were used for Rock-Eval6 analyses that were performed at the "IFP Energies nouvelles" (IFPEN, Rueil Malmaison). The Rock-Eval parameters used in this study were: (i) Total Organic Content (TOC, \%), which accounts for the quantity of OM present in the sediment; (ii) Hydrogen Index (HI, mg HC/g TOC), which is the amount of hydrocarbonaceous products released during pyrolysis normalized to TOC; (iii) Oxygen Index (OI, $\mathrm{mg} \mathrm{O}_{2} / \mathrm{g} \mathrm{TOC}$ ), calculated from the amounts of $\mathrm{CO}$ and $\mathrm{CO}_{2}$ released during pyrolysis, which gives the oxygen content of the OM; and (iv) Tmax, which is the temperature of the pyrolysis oven recorded at the maximum of $\mathrm{HC}$ production, and is a good indicator of OM maturity in ancient sediments (Espitalié et al., 1985a).

\subsubsection{Lipid extraction and separation}

28 dried and powdered samples were extracted with an Accelerated Solvent Extractor (ASE 200, Dionex@), using a dichloromethane (DCM): methanol 9:1 (v/v) solvent mixture.

Extracted lipids were then separated into a neutral and an acidic fraction by solid phase extraction using aminopropyl-bonded silica. Neutral compounds were eluted with DCM:isopropanol 2:1 and acidic compounds with ether after acidification with ether:formic acid 9:1. The neutral fractions were submitted to further fractionation on Kieselgel-type-silica 
columns to give aliphatic hydrocarbons (eluted with heptane; see Jacob et al., 2005), and other compounds including aromatic hydrocarbons which are not discussed in this paper. $5 \alpha-$ Cholestane was added as internal standard to each hydrocarbon fraction prior to analysis.

\subsubsection{GC-MS analysis}

GC-MS analyses were performed on a Thermo-Finnigan TRACE-PolarisGCQ gas chromatograph-mass spectrometer. The gas chromatograph (GC) was fitted with an Rtx-5 MS capillary column ( $30 \mathrm{~m} \times 0.25 \mathrm{~mm}$ i.d., $0.25 \mu \mathrm{m}$ film thickness) with $5 \mathrm{~m}$ of guard column. The GC operating conditions were as follows: temperature hold at $40^{\circ} \mathrm{C}$ for $1 \mathrm{~min}$, then an increase from 40 to $120^{\circ} \mathrm{C}$ at $30^{\circ} \mathrm{C} / \mathrm{min}, 120$ to $300^{\circ} \mathrm{C}$ at $5^{\circ} \mathrm{C} / \mathrm{min}$ with a final isothermal hold at $300^{\circ} \mathrm{C}$ for $30 \mathrm{~min}$. The sample was dissolved in toluene and injected splitless in a 2 $\mu \mathrm{l}$ volume, with the injector temperature set at $280^{\circ} \mathrm{C}$. Helium was the carrier gas at a flow rate of $1 \mathrm{ml} \cdot \mathrm{min}^{-1}$. The mass spectrometer was operated in the electron ionization (EI) mode at $70 \mathrm{eV}$ ionization energy and scanned from 50 to 650 Daltons. The method for biomarker quantification is described elsewhere (Lavrieux et al., 2011). Briefly: the concentration of each $n$-alkane was estimated by measuring the areas of their peaks on the $m / z 57+71+85$ ions specific chromatograms. After converting these areas into areas in Total Ion Current (TIC) by using a correction factor, the calculated peak areas were then normalized to the intensity of the peak of 5a-cholestane, measured on the TIC and to the weight of dry sample extracted.

\subsubsection{Gas chromatography-isotope-ratio mass spectrometry}

The carbon isotopic composition $\left(\delta^{13} \mathrm{C}\right)$ of $n$-alkanes and the hydrogen isotopic composition $(\delta \mathrm{D})$ of $n$-alkanes and onocerane I were determined by gas chromatography-isotope ratio mass spectrometry (GC-IRMS) using a Trace GC chromatograph equipped with a TriPlus autosampler, connected to a GC-Isolink combustion- (for $\delta^{13} \mathrm{C}$ ) or pyrolysis- (for $\delta \mathrm{D}$ ) interface, a ConFlo IV dilution system and coupled to a DeltaV Advantage isotope ratio mass spectrometer (all from Thermo Scientific, Bremen). The chromatographic conditions were the 
same as those used in GC-MS experiments, except that the GC column was slightly different (Agilent J\&W DB-5, $30 \mathrm{~m}, 0.25 \mathrm{~mm}$ i.d., $0.25 \mu \mathrm{m}$ film thickness). The analytical accuracy and precision of the system were monitored using a mixture of $n$-alkanes $\left(n-C_{16}\right.$ to $n-\mathrm{C}_{30}$, Arndt Schimmelmann, Indiana University, Bloomington, IN, USA) that was analyzed before and after each set of 4 injections. The overall precision for the $n$-alkane standard was better than $0.2 \%$ for $\delta^{13} \mathrm{C}$ and $5 \%$ for $\delta \mathrm{D} . \delta^{13} \mathrm{C}$ values based on duplicate analyses and normalized to the VPDB isotopic scale, were calculated against a calibrated $\mathrm{CO}_{2}$ gas. The same procedure was used for $\delta D$ values (with $\mathrm{H}_{2}$ as reference gas) based on triplicate analyses and normalized to the V-SMOW isotopic scale. The mean precision of the $n-\mathrm{C}_{25}, n$ $\mathrm{C}_{27}$ and $n-\mathrm{C}_{29} \delta^{13} \mathrm{C}$ values was better than $0.3 \%$. The mean precision of the $n-\mathrm{C}_{27}, n-\mathrm{C}_{29}$ and onocerane I $\delta \mathrm{D}$ was better than $6 \%$. The measured $\delta^{13} \mathrm{C}$ and $\delta \mathrm{D}$ values for the $n$-alkanes standard are in good agreement with those measured offline. The $\mathrm{H}^{+}$factor was calculated daily prior to analyses and was consistently below $4 \mathrm{ppm} \mathrm{V}^{-1}$. Because of the low amounts of biomarkers in some levels, only 20 samples could be analyzed for $\delta^{13} \mathrm{C}$ and 17 for $\delta \mathrm{D}(14$ for onocerane I).

\subsection{Carbonate analyses}

Carbonate nodules from layers $\mathrm{Nb} 1$ and $\mathrm{Nb} 2$ were analyzed with a Kiel carbonate device coupled to a Finnigan MAT delta S mass spectrometer. The carbonate $\mathrm{CO}_{2}$ was extracted with $\mathrm{H}_{3} \mathrm{PO}_{4}$ at a temperature of $70^{\circ} \mathrm{C}$. The $\delta^{13} \mathrm{C}$ and $\delta^{18} \mathrm{O}$ values obtained, based on duplicate analyses and normalized to the VPDB isotopic scale, were calculated against a calibrated $\mathrm{CO}_{2}$ gas, extracted with $\mathrm{H}_{3} \mathrm{PO}_{4}$ from a standard carbonate at $25^{\circ} \mathrm{C}$.

\section{Results}

All the data presented in this part are shown in the supplementary material.

\subsection{Bulk geochemistry}


Except for one sample, Tmax values are always below $440^{\circ} \mathrm{C}\left(422^{\circ} \mathrm{C}\right.$ on average), thus indicating an immature OM that suffered limited burial. TOC values range from 0.35 to $43 \%$ (9.4\% in average); the average TOC value is $25.6 \%$ for lignite beds, $2.75 \%$ for clay beds and $1.3 \%$ in the SAOM Member (Mb). HI values range from 15 to $272 \mathrm{mg} \mathrm{HC} / \mathrm{g}$ TOC (76 mg $\mathrm{HC} / \mathrm{g}$ TOC in average); the average $\mathrm{HI}$ value is $128 \mathrm{mg} \mathrm{HC} / \mathrm{g}$ TOC for lignite beds, $71 \mathrm{mg}$ $\mathrm{HC} / \mathrm{g}$ TOC for clay beds and $45 \mathrm{mg} \mathrm{HC} / \mathrm{g}$ TOC for the SAOM Mb. OI values range from 11 to $230 \mathrm{mg} \mathrm{O} / \mathrm{g}$ TOC (88 $\mathrm{mg} \mathrm{O}_{2} / \mathrm{g}$ TOC in average); 3 samples with implausible Ol values (more than $450 \mathrm{mg} \mathrm{O}_{2} / \mathrm{g} \mathrm{TOC}$ ) according to Behar et al. (2001) will not be further discussed. The average Ol value is $62 \mathrm{mg} \mathrm{O}_{2} / \mathrm{g}$ TOC for lignite beds, $129 \mathrm{mg} \mathrm{O} / \mathrm{g}$ TOC for clay beds, 160 $\mathrm{mg} \mathrm{O}_{2} / \mathrm{g}$ TOC for SAOM. In an HI-OI diagram, the Vasterival samples plot in the Type III field (Fig. 5), indicating that terrestrial plants are the main producers of the Vasterival OM (Espitalié et al., 1985b).

\subsection{Palynofacies}

\subsubsection{Lignite beds}

The main palynofacies results are shown on Fig. 6. Vasterival lignite beds are characterized by a high content in gelified OM from higher plant origin with an average of $81.4 \%$. The average dAOM content is $8.4 \%$; it is very low in Lb1 and Lb5 (<3\%), but reaches $25 \%$ in Lb2 and Lb4. Lb4 is the only lignite bed with a high content in fAOM (22.8\%) and in Pediastrum spp. (6.2\%; Fig. 6), whereas the average percentages for all the Vasterival lignite beds are respectively $5.2 \%$ and $1.5 \%$. The brown wood content is $1 \%$ on average (see supplementary data). Only the highest part of Lb3 (samples 95 and 98, average of 1.4 \%) and the lowest part of Lb5 (samples 143 and 147, average of $3.2 \%$ ) show higher concentrations. Cuticle proportions are low $(0.6 \%$ on average, see supplementary data). Black phytoclasts and charcoal contents are very low, with a maximum value of $1 \%$ and an average of $0.4 \%$ (see supplementary data). Spore and pollen contents are $<1 \%(0.5 \%$ on 
average) whereas the Botryococcus spp. content, with a similar average (0.6\%), reaches 1.3 \% in Lb5 and $1.7 \%$ in Lb3. Dinoflagellate cysts are observed in the Lb5 (average of $0.5 \%$; Fig. 3), where Apectodinium spp. constitutes more than $75 \%$ of the dinocyst assemblage.

\subsubsection{Pre-PETM clay beds}

Pre-PETM clay beds (Rb1, Nb1, Cb1 and Cb2) show various contents of gelified OM (8.7 $73.5 \%$, average $51 \%$; Fig. 6), and of diffuse AOM (15.5 - $84.5 \%$, average $45.8 \%$; Fig. 6). The fAOM proportions are relatively low with an average of $1.3 \%$. The brown wood content is $2 \%$ on average (see supplementary data). Cuticle proportions are relatively high with an average of $2.8 \%$ (see supplementary data). The average proportion of black phytoclasts and charcoal is $0.75 \%$ (see supplementary data). Pollen and spores are uncommon (average of $0.5 \%$ ). These clay beds show the highest Botryococcus proportion with an average of $1.6 \%$, up to $4.3 \%$ in sample $27(\mathrm{Rb} 1)$. Contents in freshwater algae Pediastrum are relatively moderate with an average of $2.1 \%$, up to $6.1 \%$ in sample 70 .

\subsubsection{PETM clay beds}

PETM clay beds (Cb3, Rb2 and Rb3) are significantly different from the pre-PETM ones, with respect to the OM content (Fig. 6). They show a higher content in dAOM (35.5 - 75.2\%, average $58 \%$ ), and in Pediastrum spp. (up to $11 \%$ in sample 136 with an average of $7.5 \%$ ). They also exhibit lower proportions of gelified OM with an average of $23.8 \%$. Brown wood proportions are $<1 \%$ (average of $0.4 \%$, see supplementary data). The values of cuticles and black phytoclasts and charcoal are relatively low, with respective averages of $1.9 \%$ and 0.5 $\%$ (see supplementary data). Higher amounts of fAOM are observed in this interval: an average of $7.3 \%$, up to $13 \%$ for the $\mathrm{Cb} 3$ and to a maximum value of $21 \%$ observed in sample 103 (Fig. 6). These high contents in fAOM are considered to indicate a significant proportion of algal organic matter in these beds (Tyson, 1995; Batten, 1996). Spores and pollen are rare (average of $0.6 \%$ ), and Botryococcus spp. are rare with an average proportion of $0.2 \%$. The first appearance of Apectodinium spp. in the Vasterival section 
occurs in this interval (sample 136). They are observed in the whole Rb3 bed where a very low content of dinoflagellate cysts is observed $(0.1 \%$ for samples 136 and $138,0.4 \%$ for samples 140; Fig. 6). This is indicative of a slight marine influence.

\subsubsection{SAOM Member}

The SAOM Mb samples (i.e. from 155 to $196 \mathrm{~cm}$ ) contain the highest proportions of dAOM of the Vasterival section with an average of $75 \%$, up to $89 \%$ in sample 189 (Fig. 6). In the SAOM Mb the $\mathrm{dAOM}$ has a greyish aspect that is not observed in any other bed. It also shows the lowest proportions of gelified OM with an average of $13.9 \%$, down to $5.1 \%$ in sample 189. The fAOM content is also very low with an average of $0.5 \%$. Cuticle content is relatively high (average of $3.6 \%$ ), whereas the black phytoclast and charcoal proportions are moderate (average of $0.75 \%$, see supplementary data). In the palynomorph group, spore and pollen proportions are here the highest in the whole section (average of $0.97 \%$ ), but the Botryococcus and Pediastrum contents are the lowest with respective averages of 0.1 and $0.3 \%$. The SAOM Mb exhibits the highest contents in dinoflagellate cysts (average of $4.5 \%$ ), with a mean proportion of Apectodinium spp. ranging from 33 to $78 \%$.

\subsection{Molecular geochemistry}

\subsubsection{Higher plant biomarkers}

The aliphatic hydrocarbon fraction is dominated by $n$-alkanes ranging from $n-C_{17}$ to $n-C_{34}$ with minor amounts of $n-\mathrm{C}_{14}$ to $n-\mathrm{C}_{16}$ and of $n-\mathrm{C}_{35}$ to $n-\mathrm{C}_{37}$ in some samples. Onocerane I was identified in most of our samples. This compound elutes between $n-\mathrm{C}_{29}$ and $n$ - $\mathrm{C}_{31} n$-alkanes with our chromatographic conditions. The mass spectrum of this original biomarker is characterized by: a molecular ion $\mathrm{M}^{+} 414$, a base peak at $\mathrm{m} / \mathrm{z} 123$ and a strong peak at $\mathrm{m} / \mathrm{z}$ 191 (Kimble et al., 1974). Onocerane I has not been found in living plants. Possible precursors have been reported in angiosperm species (Pearson and Obaje, 1999; Jacob et 
al., 2004). Considering the restricted number of potential sources, onocerane $I$ is thus considered as a more specific biomarker of higher plants than long chain $n$-alkanes.

The $n$-alkane series are dominated by long chain $\left(>n-C_{24}\right) n$-alkanes with odd-over-even predominance, which is usually associated with a significant input of OM from terrestrial vascular plants (Eglinton et al., 1962; Eglinton and Hamilton, 1967). Sample 27 is the only one that shows a dominance of short chain $n$-alkanes, indicating a significant algal contribution (Pelet, 1985). The Carbon Preference Index (CPI; Bray and Evans, 1961) was determined through the following equation:

$\mathrm{CPI}=1 / 2 \times\left(\mathrm{C}_{25}+\mathrm{C}_{27}+\mathrm{C}_{29}+\mathrm{C}_{31}+\mathrm{C}_{33}\right) /\left(\mathrm{C}_{24}+\mathrm{C}_{26}+\mathrm{C}_{28}+\mathrm{C}_{30}+\mathrm{C}_{32}\right)$

$+1 / 2 \times\left(\mathrm{C}_{25}+\mathrm{C}_{27}+\mathrm{C}_{29}+\mathrm{C}_{31}+\mathrm{C}_{33}\right) /\left(\mathrm{C}_{26}+\mathrm{C}_{28}+\mathrm{C}_{30}+\mathrm{C}_{32}+\mathrm{C}_{34}\right)$.

The numbers in the equation represent the number of carbons in an $n$-alkane molecule. This ratio is considered as a good indicator of the potential contribution of land plants to the bulk OM (Peters et al., 2005). CPI values for Vasterival samples range from 1.1 to 5.55 (3.15 on average; Fig. 7), lower than those usually observed for extant vascular plants that are $>5$ (Van Dongen et al., 2006), but still suggesting significant contributions of OM derived from land plants, as CPI values $>1$ correspond to a predominantly higher-plant input (Peters et al., 2005; Van Dongen et al., 2006; Carvajal-Ortiz et al., 2009). Other authors suggest that low CPI values could be related to significant bacterial activity (Chaffee et al., 1986; Stefanova et al., 1995). Pre-PETM lignite beds exhibit low values in comparison with the PETM ones (Fig. 7). Two clay and two lignite samples have low CPI values <2 (Fig. 7). Caution must therefore be taken before interpreting their biomarker concentrations and compound-specific isotopic composition, as they may have been strongly degraded by bacteria.

Because of the occurrence of short-chain $n$-alkanes and their potential algal origin, the terrestrial/freshwater plant ratio $\left(\mathrm{P}_{\text {aq }}\right.$; Ficken et al., 2000) can be used to assess the source of most of the long-chain $n$-alkanes. The $P_{\text {aq }}$ expresses the relative proportion of mid-chain $n$ alkanes $\left(n-\mathrm{C}_{23}, n-\mathrm{C}_{25}\right)$ produced by submerged/floating aquatic macrophytes over the amount 
of long-chain $n$-alkanes $\left(n-\mathrm{C}_{27}, n-\mathrm{C}_{29}, n-\mathrm{C}_{31}\right)$ produced by higher plants: $\mathrm{P}_{\mathrm{aq}}=\left(\mathrm{C}_{23}+\mathrm{C}_{25}\right) /$ $\left(\mathrm{C}_{27}+\mathrm{C}_{29}+\mathrm{C}_{31}\right)$. A study of the vegetation around and in present tropical African lakes revealed that submerged and floating macrophytes are characterized by $P_{\text {aq }}$ ranging from 0.4 to 1 , whereas the $P_{a q}$ of emersed plants range from 0.1 to 0.4 , and the $P_{a q}$ of terrestrial plants range from 0.01 to 0.23 (Ficken et al., 2000). In Vasterival, $P_{\text {aq }}$ values range from 0.08 to 0.47 (Fig. 7). Except for sample 27, all values are below 0.4 , suggesting that emersed and terrestrial plants are the main producers of the $n$-alkanes in Vasterival.

\subsubsection{Long-chain n-alkanes relative concentrations}

The relative proportions of $n$-alkanes $n-\mathrm{C}_{27}\left(\mathrm{C}_{27} /\left(\mathrm{C}_{27}+\mathrm{C}_{29}+\mathrm{C}_{31}\right)\right), n-\mathrm{C}_{29}\left(\mathrm{C}_{29} /\left(\mathrm{C}_{27}+\mathrm{C}_{29}+\right.\right.$ $\left.\left.\mathrm{C}_{31}\right)\right)$ and $n-\mathrm{C}_{31}\left(\mathrm{C}_{31} /\left(\mathrm{C}_{27}+\mathrm{C}_{29}+\mathrm{C}_{31}\right)\right)$ are shown on Fig. 7. Five intervals can be identified: (i) The first interval comprises the beds $\mathrm{Lb} 1$ and $\mathrm{Nb} 1$ and exhibits relatively low $n-\mathrm{C}_{27}$ proportions (average of $29.5 \%$ ) but high $n-\mathrm{C}_{29}$ and $n-\mathrm{C}_{31}$ with respective averages of 44.5 and $26 \%$; (ii) The second interval comprises the beds Cb1, Lb2, Cb2 and Lb3 and shows moderate proportions of $n-\mathrm{C}_{27}$ and $n-\mathrm{C}_{31}$ (respective averages of 39 and $19.6 \%$ ), compared to high percentages of $n-\mathrm{C}_{29}$ (average $41.5 \%$ ); (iii) The third interval corresponds to the $\delta^{13} \mathrm{C}_{\text {org }}$ excursion and differs from all the other intervals by high proportions of $n-C_{27}$, ranging from 44 to $59.6 \%$ (average $55 \%$ ); (iv) The Lb5 bed shows the return to pre-PETM proportions of $n-\mathrm{C}_{27}, n-\mathrm{C}_{29}$ and $n-\mathrm{C}_{31}$ (37, 43 and $20 \%$, respectively); (v) In the SAOM Mb, sample 162 exhibits the highest $n-C_{31}$ percentage (32\%) unlike samples 175 and 196 (respectively, 23 and $20 \%$ ), samples 162 and 175 are dominated by $n-C_{29}$ (average of 41.5 $\%)$, whereas sample 196 shows a clear dominance of $n-\mathrm{C}_{27}(44 \%)$.

Studies of the $n$-alkane and pollen distributions in recent sediments showed a relation between the $n$-alkane distribution and the type of vegetation (i.e. boreal, tropical, etc.). These studies pointed out that vegetation subjected to harsh conditions, such as arid or boreal climates, has a clear dominance of $n-\mathrm{C}_{31}$ over $n-\mathrm{C}_{29}$ and $n-\mathrm{C}_{27}$ (Schwark et al., 2002; Rommerskirchen et al., 2003). They also showed that vegetation growing under more 
favorable climatic conditions (i.e. equatorial or temperate) has a much higher proportion of $n$ $\mathrm{C}_{27}$ and $n-\mathrm{C}_{29}$. Therefore, the dominance of $n-\mathrm{C}_{27}$ and $n-\mathrm{C}_{29}$ in Vasterival sediments suggests that the vegetation did not experience long periods of overall semi-arid conditions.

\subsection{3. $n$-alkane compound-specific $\delta^{13} \mathrm{C}$ values}

As there are potential changes in OM-source throughout the Vasterival section that could, in part, be responsible for changes in bulk $\delta^{13} \mathrm{Corg}, \delta^{13} \mathrm{C}$ values were determined for the $\mathrm{C}_{25}$, $\mathrm{C}_{27}$ and $\mathrm{C}_{29} n$-alkanes that are mainly derived from higher plant epicuticular waxes (Eglinton et al., 1962). $n-C_{25} \delta^{13} \mathrm{C}$ values range from -27.9 to $-33 \%$, whereas $n-C_{27} \delta^{13} \mathrm{C}$ values range from -29.3 to $-34.3 \%$ and $n-C_{29} \delta^{13} \mathrm{C}$ values range from -28.6 to $-32.6 \%$ (Fig. 8).

Except for one sample, the $n-C_{29}$ is less depleted in ${ }^{13} \mathrm{C}$ than the $n-\mathrm{C}_{27}$, the offset between the $2 n$-alkanes ranging from -0.1 to $2.2 \%$ (Fig. 8). The $n$ - $\mathrm{C}_{25}$ sometimes shows more negative values than the $n-C_{27}$ and sometimes less negative than the $n-C_{29}$. The $\delta^{13} \mathrm{C}$ values of all three $n$-alkanes show almost identical trends throughout the section.

Below $98 \mathrm{~cm}$, values vary between -28.6 and $-31 \%$ (average of $-29.5 \%$ ) for $n-C_{29}$, between -29.3 and $-31.1 \%$ (average of $-30.14 \%$ ) for $n-\mathrm{C}_{27}$ and between $-27.9 \%$ and $-31.4 \%$ (average of $-30 \%$ ) for $n-C_{25}$. At $98 \mathrm{~cm}, \delta^{13} \mathrm{C}$ values for all three $n$-alkanes start to shift towards more negative values, reaching $-32.6 \%$ for $n-C_{29},-33.1 \%$ for $n-C_{27}$ and $-32 \%$ for $n-\mathrm{C}_{25}$ at $103 \mathrm{~cm}$.

The next three samples upwards show less negative values: slightly below $-29.6 \%$ for $n-C_{29}$, below -30.5 for $n-C_{27}$ and up to $-30.7 \%$ for $n-C_{25}$, which are more negative values than the Upper Paleocene ones. After this positive peak, another negative shift is observed: $\mathrm{C}_{27}$ and $\mathrm{C}_{25} n$-alkanes reach their most negative values at $130 \mathrm{~cm}$, with $-34.30 \%$ for $n-\mathrm{C}_{27}$ and $-33 \% 0$ for $n-C_{25}$. A second positive shift that is less pronounced than the first one occurs between 136 and $143 \mathrm{~cm}$. At $143 \mathrm{~cm}$ all three $n$-alkanes show $\delta^{13} \mathrm{C}$ values below $-30.6 \%$, which is more negative than the pre-excursion average values. The last terrestrial samples show another negative shift reaching $-31.6 \%$ for $n-\mathrm{C}_{29},-32.7 \%$ for $n-\mathrm{C}_{27}$ and $-31.6 \%$ for $n-\mathrm{C}_{25}$. In 
the SAOM Mb, the three $n$-alkanes show a positive trend, reaching $-30.4 \%$ for $n-C_{29},-31.5$ $\%$ for $n-C_{27}$ and $-31.1 \%$ for $n-C_{25}$, again more negative than the Upper Paleocene values. Thus, the negative excursion, which begins at $98 \mathrm{~cm}$, is interpreted as the PETM CIE, and the magnitude of this excursion is $3.5 \%$ for $n-\mathrm{C}_{29}, 4.5 \%$ for $n-\mathrm{C}_{27}$ and $3 \%$ for $n-\mathrm{C}_{25}$.

\subsection{4. compound-specific $\delta D$ values}

$\delta \mathrm{D}$ values were determined for $\mathrm{C}_{27}$ and $\mathrm{C}_{29} n$-alkanes and onocerane I. Concentrations of the $\mathrm{C}_{25} n$-alkane were too low to allow reliable $\delta \mathrm{D}$ analyses. Along the section, the same trends are observed for the $\delta \mathrm{D}$ of both $n$-alkanes and onocerane I, $n-\mathrm{C}_{29}$ and onocerane I being generally more depleted in $\mathrm{D}$ than the $n-\mathrm{C}_{27}$ (Fig. 8).

In the pre-PETM part of the section, $\delta D$ values range from -174 to $-112 \%$ for $n-C_{27}$, from 186 to $-110 \%$ for $n-C_{29}$ and from -179 to $-127 \%$ for onocerane I. The lowest values are observed in clay samples whereas the highest values are observed in lignite beds. A marked increase in $\delta \mathrm{D}$ values is observed between sample 51 (Cb1) and sample 78 (Lb2), from -171 to $-124 \%$ for $n-\mathrm{C}_{27}$, from -182 to $-115 \%$ for $n-\mathrm{C}_{29}$ and from -179 to $-127 \%$ for onocerane I. $\delta D$ values reach the most negative values over the Vasterival section for sample 85 , followed by the least negative $\delta D$ values in the Lb3 lignite (sample 95).

The onset of the CIE is concomitant with a strong decrease in $\delta \mathrm{D}$ values, which reach a minimum in sample 106. The resulting negative shift reaches $50 \%$ for $n-C_{27}, 63 \%$ for $n-C_{29}$ and $55 \%$ for onocerane I. Then, the $\delta \mathrm{D}$ values remain relatively constant upward in the terrestrial part of the section, except for sample 120 (Rb3), where $\delta D$ values reach $-142 \%$ for both $n$-alkanes and $-149 \%$ for onocerane I, constituting the first positive shift of the CIE. The last sample (196) lies within the SAOM Mb and shows a second positive shift of $22 \%$ for $n-C_{27}$ and $28 \%$ for $n-C_{29}$ when compared to Lb5 (sample 149). Low onocerane I concentrations in Lb5 did not permit $\delta D$ measurements.

4.4. Carbonate carbon and oxygen isotopic compositions 
Carbonate nodules from both levels exhibit very low $\delta^{13} \mathrm{C}$ and $\delta^{18} \mathrm{C}$ values compared to usual pedogenetic carbonates (Cerling, 1984; Cerling and Quade, 1993). The $\delta^{13} \mathrm{C}$ values are $-27 \%$ for the $\mathrm{Nb} 1$ and $-21.7 \%$ for the $\mathrm{Nb} 2$, and the $\delta^{18} \mathrm{O}$ values are $-22 \%$ for the $\mathrm{Nb} 1$ and $17.2 \%$ for the $\mathrm{Nb} 2$.

\section{Discussion}

\subsection{Refining the PETM extension in Vasterival}

The CIE is the primary criterion of the PETM (Kennett and Stott, 1991; Aubry et al., 2007). To verify the presence of the CIE in a section devoid of carbonates, most of the current studies are based on the isotopic composition of bulk OM. However, it has been demonstrated that marine and terrestrial OM do not have the same $\delta^{13} \mathrm{C}$ signature (Meyers, 1997), and that even in the terrestrial OM, gymnosperms and angiosperms do not have the same $\delta^{13} \mathrm{C}$ signature (Leavitt and Newberry, 1992; Chikaraishi and Naraoka, 2003). The PETM is also characterized by secondary criteria such as: the benthic foraminiferal extinction event in the marine realm (Kennett and Stott, 1991) and the Apectodinium acme in marine and brackish paleoenvironments (Bujak and Brinkhuis, 1998; Crouch et al., 2003), although Sluijs et al. (2007) observed that the Apectodinium acme can precede the CIE. In Vasterival, the beginning of the marine influence occurs in the Rb3 clay, as indicated by the first occurrence of Apectodinium dinoflagellate cysts, $19 \mathrm{~cm}$ below the SAOM Mb (Fig. 6; supplementary data). This coincides with the return to more positive values of $\delta^{13} \mathrm{C}_{\text {org }}$ that could be interpreted as the recovery of the CIE (Storme et al., 2012b). However, the occurrence of the Apectodinium acme in the SAOM Mb suggests that these deposits are encompassed within the PETM event (Bujak and Brinkhuis, 1998; Crouch et al., 2003; Aubry et al., 2007). Vasterival samples all plot in the Type III (higher plant) part of the Van Krevelen diagram (Fig. 5). Nevertheless, Espitalié et al. (1985b) have shown that the degradation of OM causes a decrease in the $\mathrm{H} / \mathrm{C}$ ratio as well as in $\mathrm{HI}$ values; a degraded marine OM can thus 
exhibit $\mathrm{OI}$ and $\mathrm{HI}$ values characteristic of terrestrial OM. SAOM Mb sediments contain numerous coquina and sandy layers that are indicative of a high energy environment generally associated with good oxygenation. It is therefore likely that the OM in these deposits has been subjected to degradation. In addition, palynofacies data show that dAOM, which can either derive from marine or terrestrial organic matter (Tyson, 1995; Batten, 1996), is dominant in the SAOM Mb. The dAOM has also a grayish and fluffy aspect that could indicate an oxidized OM (Tyson, 1995). The marine palynomorphs represent $40 \%$ of total palynomorphs (on average) in the SAOM Mb, indicating a significant contribution of marine $\mathrm{OM}$ in those deposits. Furthermore, some authors have revealed that angiosperms and gymnosperms have a differential carbon fractionation during carbon assimilation (Schouten et al., 2007; Smith et al., 2007). Therefore, the less negative values of the bulk-CIE from Rb3 upwards could be interpreted as a result of the increasing influence of marine OM, as marine OM is generally less ${ }^{13} \mathrm{C}$ depleted than terrestrial OM (Meyers, 1997), and/or a change in plant community (Leavitt and Newberry, 1992; Chikaraishi and Naraoka, 2003; Smith et al., 2007).

From the $\delta^{13} \mathrm{C}$ measurements performed on higher-plant derived $n$-alkanes $\left(n-\mathrm{C}_{25}, n-\mathrm{C}_{27}\right.$ and $n-C_{29}$ ), a contribution from algal material, that can affect bulk $\delta^{13} \mathrm{C}$ (Meyers, 1997), can be excluded. All three $n$-alkanes record the beginning of the CIE by a significant negative shift in sample 98, i.e. just slightly before the onset of the bulk $\delta^{13} \mathrm{C} \mathrm{CIE}$. The amplitude of the excursion is greater than $3.4 \%$ for all three $n$-alkanes. As we do not observe any return to pre-excursion $\delta^{13} \mathrm{C} n$-alkane values in the Vasterival section and as the Apectodinium acme is recorded from sample $136 \mathrm{~cm}$ to the top of the section, we can propose that the SAOM Mb sediments of Vasterival are encompassed within the PETM. If correct, the sediments of the upper half of the section were thus deposited in less than 120-220 ka, depending on estimations of the PETM duration (Röhl et al., 2007; Aziz et al., 2008; Murphy et al., 2010). Preliminary palynological analyses on Vasterival samples showed an increase in gymnosperm pollen between 138 and $143 \mathrm{~cm}$ (Roche, pers. comm.), coincident with a 
positive shift in the $n$-alkanes $\delta^{13} \mathrm{C}$ (Fig. 8). Yet, it has been shown that gymnosperm $n$ alkanes are more ${ }^{13} \mathrm{C}$ enriched compared to $n$-alkanes found in angiosperms grown under the same climatic conditions (Leavitt and Newberry, 1992; Chikaraishi and Naraoka, 2003; Smith et al., 2007; Diefendorf et al., 2010). Thus, the positive shift in the $n$-alkanes $\delta^{13} \mathrm{C}$ recorded in this interval may be related to a change in the floral assemblage.

These source-mixing effects may explain the zigzag shape of several $\delta^{13} \mathrm{C}_{\text {org }}$ records in the "Sparnacian" deposits of the Paris Basin (Sinha, 1997; Thiry and Dupuis, 1998; Magioncalda et al., 2001; Thiry et al., 2006), the London Basin (Collinson et al., 2007) and North Belgium (Steurbaut et al., 2003). This similarity suggests that the PETM extension in these areas may be larger than previously thought. This possibility would have important stratigraphical consequences since the negative peaks of $\delta^{13} \mathrm{C}_{\text {org }}$ records were used for regional correlation (Thiry and Dupuis 1998; Thiry et al., 2006)

\subsection{Evolution of depositional environment}

\subsubsection{Latest Paleocene}

The lignite complex L1 of the Cap d'Ailly section is interpreted to have been deposited in a swamp (Magioncalda et al., 2001). However, high resolution observations reveal a complex succession of clay and organic-rich beds that could be related to a more dynamic depositional environment than previously thought.

The Rb1 differs from all the other terrestrial beds of the Vasterival section by having a large proportion of short-chain $n$-alkanes $\left(<n \mathrm{C}_{19}\right)$, pointing to a significant algal contribution (Pelet, 1985). Furthermore, sample 27 is the only one with a $P_{a q}$ ratio $>0.4$ that indicates a dominance of submerged-floating plants over terrestrial and emersed plants (Ficken et al., 2000). Consistently, the proportion of aquatic OM (i.e. fAOM, Pediastrum spp. and Botryococcus spp.) reaches $11.5 \%$, including $4.3 \%$ of Botryococcus spp. that are commonly observed in lake sediments (Batten, 1996). In agreement with the lithostratigraphy of the 
Côte d'Albâtre succession (Fig. 2), Rb1 can be viewed as the terminal unit of lacustrine deposits. The very low $\mathrm{HI}$ value found in $\mathrm{Rb} 1$ (29 $\mathrm{mg} \mathrm{HC} / \mathrm{g} \mathrm{TOC}$ ) is unusual for lacustrine deposits but can be explained by a strong degradation of OM, as shown by a low CPI (Stefanova et al., 1995). As a matter of fact, numerous root traces originating from the overlying L1 lignite complex indicate the development of an autochthonous peat formation (Bennett, 1964; Cohen, 1970; Diessel, 1992) that marks the end of the lacustrine episode.

The Lb2 and Lb3 beds do not exhibit rooted floor sediments but are laminated. This feature is interpreted as the deposition of allochthonous peat material alternating with clay particles (Bennett 1964; Cohen, 1970). Peatlands are usually associated with dysoxic to anoxic conditions. This paleosetting at Vasterival is confirmed by high TOC values (average of 23 $\%$ ) and by strong bacterial activity evidenced by the dominance of gelified particles (mean of $84 \%$ ), interpreted as the result of bacterial degradation (Batten, 1996; Pacton et al., 2011). The $\mathrm{P}_{\mathrm{aq}}$ values (average of 0.16 ; Fig. 7) indicate a combination of terrestrial and emersed plant $n$-alkanes in those beds (Ficken et al., 2000).

The clay beds $\mathrm{Cb} 1$ and $\mathrm{Cb} 2$ also exhibit relatively high TOC values (average of $4.1 \%$ ) suggesting that they were deposited in a dysoxic to anoxic environment. The proportion of gelified particles (average of $63 \%$ ) is again indicative of strong bacterial activity (Batten, 1996; Pacton et al., 2011). The $P_{\text {aq }}$ values are higher than those observed in the pre-PETM lignite beds (average of 0.18 ). This difference may indicate a higher contribution of emersed plants in $\mathrm{Cb} 1$ and $\mathrm{Cb} 2$ beds than in the lignite ones. Therefore, in Vasterival, clay beds are likely to have been formed in an environment with a water level higher than the one that prevailed during lignite formation.

Carbonate nodules found in levels $\mathrm{Nb} 1$ and $\mathrm{Nb} 2$ exhibit low $\delta^{13} \mathrm{C}$ values (respectively $-27 \%$ and $-21.7 \%$ ) in comparison with the PETM-soil-carbonate nodules of the Polecat Bench section (- 9 to - $15 \%$; Wyoming; Bains et al., 2003). These very negative values can be compared to those obtained by Whelan and Roberts (1973) in poorly-drained swamp 
sediments. In environments showing similar redox conditions, Raiswell (1988) explains that

${ }^{13} \mathrm{C}$-depleted carbonate nodules are formed diagenetically. This process only occurs in a thin zone below the water-sediment interface, under a combination of sulfate reduction and anaerobic methane oxidation, associated with low or null sedimentation rates.

Furthermore, the very negative $\delta^{18} \mathrm{O}$ values $(-22 \%$ for $\mathrm{Nb} 1$ and $-17.2 \%$ for $\mathrm{Nb} 2)$ found in those nodules indicate that part of the oxygen originated from organic matter by bacterial reduction of sulphate and fermentation (Sass et al., 1991), two reactions producing $\mathrm{HCO}_{3}{ }^{-}$ (Raiswell, 1988; Sass et al., 1991). The rest of the oxygen is likely to originate from the environment waters (Coleman and Raiswell, 1980). It is thus hazardous to interpret these results in terms of environment-water or groundwater isotopic composition.

All these sediments are likely to have been deposited in a relatively closed marsh environment. After the Rb1 bed, which represents the former lacustrine environment, the Lb1 peaty bed marks the setting of the marsh. The clay to peat deposition variation may therefore be linked to water level changes: a high water level would have drowned peat vegetation and is thus favorable to emergent plants such as reeds, but also to more clastic inputs as a too great turbidity is considered unfavorable to a peat environment (Diessel, 1992). As a matter of fact, Unio shells are found in $\mathrm{Cb} 1, \mathrm{Lb} 2, \mathrm{Cb} 2$ and $\mathrm{Lb} 3$ beds, which also indicates low clastic inputs (Burky, 1983; Good, 2004). Therefore, each type of deposit can be explained by a combination of these parameters: (i) lignite beds correspond to low clastic inputs and relatively low water table, (ii) clay beds are deposited when there is a combination of moderate clastic inputs and a higher water table.

\subsubsection{Early PETM}

The beginning of the PETM coincides with abrupt changes in OM distribution. Palynofacies indicate a clear dominance of $\mathrm{dAOM}$ in clay beds (average $58 \%$ ) but also high proportions of Pediastrum algae between samples 101 and 140 (average $7.2 \%$; Fig. 6). A high amount of Pediastrum is generally associated with eutrophic freshwater environments, and thus, with 
strong seasonal nutrient inputs (Nielsen and Sørensen, 1992; Tyson, 1995; Guy-Ohlson, 1996). Furthermore, the Cb3 bed shows high proportions of fAOM (average of $13 \%$ ), which supports a strong algal contribution (Tyson, 1995; Batten, 1996). This contribution is consistent with the relatively higher $\mathrm{HI}$ values observed in this bed (mean value of $115 \mathrm{mg}$ $\mathrm{HC} / \mathrm{g}$ TOC). The Cb3 bed exhibits relatively higher $\mathrm{P}_{\mathrm{aq}}$ values with an average of 0.27 that is suggestive of a floral assemblage dominated by emergent plants such as reeds (Ficken et al., 2000). In addition, the disappearance of Unio in these beds could indicate enhanced detrital inputs (Burky, 1983; Good, 2004). Therefore, the beginning of the PETM in Vasterival appears to be marked by a stronger water flow that may have allowed the development of emergent vegetation and phytoplankton blooms, causing eutrophication of the environment water column.

The Lb4 lignite bed also contains high proportions of fAOM and Pediastrum spp. (respectively 22.8 and $6.1 \%$ ) and relatively higher $\mathrm{HI}$ values $(271 \mathrm{mg} \mathrm{HC} / \mathrm{g} \mathrm{TOC}$ ) that indicate a relatively strong algal contribution (Espitalié et al. 1985b; Tyson, 1995; Batten, 1996). However, the $P_{\text {aq }}$ ratio (0.14) and the proportion of gelified OM (42.5\%) indicate a strong contribution of terrestrial OM (Batten, 1996; Ficken et al., 2000). As this lignite bed overlies a clay level without root traces, the peat material is more probably allochthonous, similar to the floating mats known in Louisiana, for example (Bennett, 1964; Diessel, 1992; Visser and Sasser, 2009).

The Rb2 and Rb3 beds show similar palynofacies patterns with relatively high dAOM and Pediastrum spp. contents (respective averages of 57.6 and $7 \%$ ) and low fAOM contents (average of $3.5 \%$ ). Samples 115, 120 and 127 correspond to the green-colored part of the $\mathrm{Rb} 2$ bed. They exhibit low TOC (average $0.8 \%$ ), low HI values (average $36 \mathrm{mg} \mathrm{HC} / \mathrm{g} \mathrm{TOC}$ ), relatively low gelified particle contents (average $21 \%$ ) and moderate $\mathrm{P}_{\mathrm{aq}}$ values (average 0.19). As the CPI values are relatively high (average 3.6), these characteristics cannot be explained by degradation processes linked to soil development (Chaffee et al., 1986; Stefanova et al., 1995). Thus, we suggest that these samples were deposited in an 
environment dominated by terrestrial and emersed plants, as indicated by the $\mathrm{P}_{\mathrm{aq}}$ values. This type of environment appears unfavorable to OM preservation (Espitalié et al., 1985b), but is probably prone to temporary eutrophication, consistent with the high content in Pediastrum spp. (Nielsen and Sørensen, 1992; Tyson, 1995; Guy-Ohlson, 1996). However, the relatively low proportion of $\mathrm{AOOM}$ indicates an environment less favorable to algae proliferation than the one that prevailed during deposition of the Cb3 and Lb4 beds.

Sample 130 corresponds to the darker part of the Rb2 clay bed (Fig. 3). It shows relatively higher TOC (5.5\%) and IH values (around $175 \mathrm{mg} \mathrm{HC} / \mathrm{g}$ TOC) along with a relatively higher $P_{a q}$ value (0.27). This combination suggests that this black clay was deposited in a eutrophic environment, dominated by emersed plants, thus favoring OM preservation.

Sample 136 shows similar palynofacies, Rock-Eval and biomarker values to the dark-colored part of the Rb2 bed, suggesting similar environmental conditions. As for samples 138 and 140, they show similar values to the light-colored part of the Rb2 bed. The main difference between the two beds is the presence of a few dinoflagellate cysts in Rb3, indicating an enhanced marine influence, as in a swamp connected to a low delta plain or an estuary (Diessel, 1992; Schobert, 1995).

The Lb5 bed is an autochthonous peat deposit as it overlies a bed with root traces (Bennett, 1964; Diessel, 1992). The relative abundance of dinoflagellates increases from base to top, thus suggesting an increasing marine influence (Fig. 6; supplementary data). Therefore, the $\mathrm{Rb3}$ and Lb5 beds were probably deposited in a swamp linked to a deltaic or estuarine system (e.g. Breyer, 1984; Schobert, 1995). Magioncalda et al. (2001) described similar evidence (e.g. presence of estuarine gastropods) in the L1 complex of the Phare d'Ailly section, which is located only $900 \mathrm{~m}$ from the Vasterival section.

Summarizing, in Vasterival, the very beginning of the PETM underwent a major environmental change, shifting from a closed, quiescent environment to a temporarily open eutrophic one, mainly dominated by emersed plants, which did not suffer from major changes 
until the beginning of the marine influence and a transitional shift to a lagoonal environment (Fig. 9). While it is hazardous to constrain the timing of pre-CIE variations in Vasterival, if we hypothesize that the deposition rate remained almost the same as during the CIE, we can assume that paleoenvironmental variations are at multi-millennial scales.

\subsection{Paleohydrological evolution}

\subsubsection{Interpretation of $n$-alkane $\delta D$ values}

According to Sachse et al. (2012), the hydrogen isotopic composition (סD) of higher plantderived leaf wax $n$-alkanes is impacted, in order of increasing importance, by: (i) the $\delta D$ values of meteoric waters, which are affected by the source of moisture, the temperature at the precipitation site and the amount of precipitation (Dansgaard 1964; Epstein and Yapp, 1976; Sauer et al., 2001; Chikaraishi and Naraoka, 2003; Sachse et al., 2004); (ii) the extent of soil-water evaporation and leaf-water transpiration, which depend on temperature and humidity (Smith and Freeman, 2006; Feakins and Sessions, 2010); (iii) interspecific variability, which depends on the plant photosynthetic pathway, physiology and biochemistry (Smith and Freeman, 2006; Chikaraishi and Naraoka, 2007); (iv) local environmental parameters that are very likely buffered when molecular biomarkers are integrated into sedimentary archives (Bossard et al., 2011).

In the Vasterival section, $\delta D$ values range from -174 to $-112 \%$ for the $C_{27} n$-alkane and from -185 to $-110 \%$ for the $\mathrm{C}_{29} n$-alkane (Fig. 8). The $n-\mathrm{C}_{29} \delta \mathrm{D}$ values of Vasterival at the Paleocene-Eocene boundary are less negative than those reported in the Bighorn Basin (195 to $-185 \%$; Smith et al., 2007) and the Arctic (-210 to $-160 \%$; Pagani et al., 2006), but comparable to those recorded in Tanzania (-160 to $-115 \%$; Handley et al., 2012), and New Zealand (-165 to $-140 \%$; Handley et al., 2011) for the same time interval. This pattern is expected, because during the PETM the Vasterival site was located in a coastal region and close to the origin of precipitation water, much like the sites in Tanzania and New Zealand. In contrast, at that time, the Arctic was a high-latitude site and the Bighorn Basin was an intra- 
continental basin: both located far from precipitation source waters and thus characterized by more D-depleted meteoric waters. Thus, it seems that the relations of those sites are in agreement with a latitudinal $\delta D$ pattern of precipitation (Bowen and Revenaugh, 2003). Hence, it is likely that $\delta D$ variations in Vasterival were not driven by a change of the source of precipitation.

Onocerane I precursors are found in only a few angiosperm species (Pearson and Obaje, 1999; Jacob et al., 2004). This biomarker is thus considered more source-specific than long chain $n$-alkanes. It can therefore be concluded that the $\delta D$ of onocerane is not affected by vegetation changes. Considering that the $\delta \mathrm{D}$ values of onocerane I and those of the $n-C_{27}$ and $n-\mathrm{C}_{29}$ alkanes show the same trends in Vasterival (Fig. 8), variations in the $n$-alkane $\delta \mathrm{D}$ values are also unlikely to be driven by changes in plant communities. Therefore, variations in compound-specific $\delta \mathrm{D}$ values can be principally interpreted as paleohydrological changes.

\subsubsection{Latest Paleocene}

In the Vasterival section, the latest Paleocene is marked by considerable variations in $\delta \mathrm{D}$ values. These changes are rather well correlated with the lithology: the least negative values are reported in lignite beds (Lb2 and Lb3) whereas the most negative values are found in clay beds ( $\mathrm{Cb} 1$ and $\mathrm{Cb} 2)$. This pattern is in agreement with the hypothesis that, before the PETM, lignite beds were formed under lower meteoric water inputs, in comparison with clay beds. Furthermore, the magnitudes of the $\delta \mathrm{D}$ variations are very high, reaching $70 \%$ between samples 78 and 85 , and $75 \%$ between samples 85 and 95 for the $n-C_{29}$. If these magnitudes are strictly interpreted in terms of changes in the amounts of rainfall, they appear to indicate an alternation between dry and wet conditions (Smith and Freeman, 2006; Feakins and Sessions, 2010). It is however probable that these changes were less marked, but were accompanied by an increase in evapotranspiration causing an overestimation of the paleohydrological changes, as an interpretation of these variations solely as 
paleohydrological changes indicates an arid environment, which is hardly compatible with swamp deposits.

The highest $\delta D$ value is found just before the CIE onset, suggesting that drier conditions predated the PETM. As previously proposed by Storme et al. (2012b), Vasterival constitutes another site where climatic variations are recorded just below the CIE onset, as at Cobham in England, where evidence of increased seasonality has been observed (Collinson et al., $2007 ; 2009)$; but also in northern Italy where the magnitude of the $\delta \mathrm{D}$ variations is slightly lower than at Vasterival (15\%o; Tipple et al., 2011) and also in the Bighorn Basin where warmer conditions have been reported (Secord et al., 2010). This similarity suggests that these pre-PETM changes were global and probably present a key to understand the processes that triggered the PETM.

One explanation of these pre-CIE changes could be a strong episode of volcanic activity in the North Atlantic Igneous Province, leading to an increase in atmospheric $\mathrm{CO}_{2}$ levels, and thus, to a progressive warming. This hypothesis is in good agreement with the conclusions of Secord et al. (2010) based on similar evidence in the Bighorn Basin. The progressive warming and the strong volcanic episode could have triggered a series of events such as the destabilization of marine clathrates (Dickens et al., 1995; 1997) and the uplift of epicontinental seas (Gavrilov et al., 1997; Higgins and Schrag, 2006), which led to the PETM.

\subsubsection{Early PETM}

The beginning of the PETM is characterized by a $60 \%$ negative shift in $n-\mathrm{C}_{29} \delta \mathrm{D}$ values, indicative of moister conditions (Smith and Freeman, 2006; Feakins and Sessions, 2010). This change is substantiated by an increase in the $n-C_{27}$ relative concentration accompanied by a dramatic increase in Pediastrum algae and in fAOM (Fig 9), which also indicates an increasing rainfall pattern during this episode (Nielsen and Sørensen, 1992; Tyson, 1995; Batten, 1996; Guy-Ohlson, 1996; Schwark et al., 2002; Rommerskirchen et al., 2003). As the 
CIE is associated with global warming (Kennett and Stott, 1991; Zachos et al., 2003;

Mclnerney and Wing, 2011), it is likely that evapotranspiration and soil-water evaporation were stronger than during the Late Paleocene. However, stronger evapotranspiration and evaporation lead to less negative $\delta D$ values (Smith and Freeman, 2006; Feakins and Sessions, 2010). As the $\delta D$ values integrate these changes as well as changes in the amount of precipitation, attributing these values solely to precipitation would underestimate these changes. Thus, during the earliest PETM at Vasterival, it is probable that precipitation was more abundant than suggested by the compound-specific $\delta D$ values.

A shift towards less negative $\delta \mathrm{D}$ values is observed in the Cb3 bed (30\% $n-\mathrm{C}_{29}$; Fig. 8), along with a strong decrease in fAOM (Fig. 6). These lines of evidence could reflect a short episode of drier conditions. After this peak, $\delta D$ values are relatively stable, suggesting that no major hydrological change occurred during this interval. In the lignite bed Lb5, this stability could result from greater water availability as a consequence of the connection of the swamp environment with the sea shown by the presence of dinoflagellates. The top of the section shows slightly higher $\delta \mathrm{D}$ values, suggestive of drier conditions.

Thus, the early PETM appears wetter than the latest Paleocene, but it was affected by at least one dry episode.

A moister climate is also indicated by several PETM records from western Europe during the PETM. In northern Italy, this evidence consists of a $15 \%$ decrease in $n$-alkane $\delta D$ values (Tipple et al., 2011). In England, a decline of wildfire evidence from the latest Paleocene to the early PETM is accompanied by an increase in wetland plants (Collinson et al., 2007; 2009). In northern Spain, extreme seasonal precipitation events occurred at the PaleoceneEocene boundary (Schmitz and Pujalte, 2007). Thus it seems that, in several regions of Western Europe, the latest Paleocene was characterized by dry conditions until the beginning of the PETM when a moister climate became established.

\subsubsection{Evidence of stronger seasonality during the earliest PETM}


The evolution of paleohydrological conditions in the Vasterival section is reconstructed from several parameters ( $n$-alkane $\delta \mathrm{D}, n$-alkane ratio, Pediastrum spp. content and fAOM content) that are all in rather good agreement. In a previous study on the same section, Storme et al. (2012b) used the $\delta^{15} \mathrm{~N}$ of organic matter $\left(\delta^{15} \mathrm{~N}_{\text {org }}\right.$; Fig. 9) as a paleohydrological/paleotemperature indicator, with more positive values pointing to drier and/or warmer conditions (Austin and Vitousek, 1998; Handley et al., 1999; Amundson et al., 2003; Liu and Wang, 2010).

Although they both record alternations of dry and humid periods prior to the PETM, the variations in $\delta^{15} \mathrm{~N}_{\text {org }}$ and $n$-alkane $\delta \mathrm{D}$ values are globally anti-correlated, thus leading to opposite interpretations if both proxies are interpreted solely as indicators of past hydrological conditions (Fig. 9).

Like the $\delta D$, the $\delta^{15} \mathrm{~N}$ of $\mathrm{OM}$ depends not only on humidity but also on other factors such as denitrification of $\mathrm{NO}_{3}$ in oxygen depleted waters (Cline and Kaplan, 1975; Meyers, 1997), humification of OM in soils (Kramer et al., 2003), and changes in OM producers (algal or terrestrial; Meyers, 1997), although Storme et al. (2012b) excluded the latter cause for Vasterival. Drainage and influence of litter could explain the discrepancy between $\delta^{15} \mathrm{~N}_{\text {org }}$ and ¿D (Shearer and Kohl, 1986; 1988; 1993). Nitrate in soils on lower slopes and near saline seeps has a higher $\delta^{15} \mathrm{~N}$ value than nitrate in well-drained soils (Karamanos et al., 1981). This property suggests the occurrence in the study area of immature, poorly-drained soils, generating relatively high $\delta^{15} \mathrm{~N}_{\text {org }}$, which could agree with enhanced seasonality (see below). Climatic variations impact $\delta^{15} \mathrm{~N}_{\text {org }}$ and $n$-alkane $\delta \mathrm{D}$ by different processes: leaching and gas emissions in soil for $\delta^{15} \mathrm{~N}_{\text {org }}$ (Swap et al. 2003; Liu and Wang, 2008; 2010), as opposed to the extent of soil-water evaporation and leaf-water transpiration for $n$-alkane $\delta D$ (Smith and Freeman, 2006; Feakins and Sessions, 2010). Sachse et al. (2009) showed that leaf-wax nalkanes found in soils and litter were produced during the growing season, thus suggesting that $n$-alkane $\delta \mathrm{D}$ variations do not record paleohydrological changes for the entire year. On 
the other hand, $\delta^{15} \mathrm{~N}_{\text {org }}$ may be mainly driven by leaching during the wet season and gas emission during the dry season (Amundson et al., 2003; Aranibar et al., 2004). The apparent discrepancy between $\delta^{15} \mathrm{~N}_{\text {org }}$ and $\delta \mathrm{D}$ could be related to changes in seasonality, thus suggesting an enhanced seasonality during the earliest PETM in Vasterival. This possibility is supported by the increase in Pediastrum spp. and in $\mathrm{fAOM}$, indicative of algal blooms, which are generally associated with strong seasonal nutrient inputs (Tyson, 1995; Batten, 1996; Sarmaja-Korjonen et al., 2006).

In the Paris Basin, palynological data (Cavagnetto, 2000) and the presence of calcrete (Bignot, 1984; Thiry et al., 2006) point to an alternation of dry and wet seasons during the earliest Eocene. Thus, it is likely that the southern part of the Dieppe-Hampshire Basin, which is only a few tens of kilometers away from the Paris Basin, underwent similar climatic changes.

An increasing seasonality is also well documented in northern Spain, in western Colorado and in New Jersey where higher rates of erosion point to a stronger weathering of the bedrock (Schmitz and Pujalte, 2003, 2007; John et al., 2012; Foreman et al., 2012), and in the Bighorn Basin where paleosols record evidence of alternating dry/wet cycles (Wing et al., 2005; Retallack, 2005; Kraus and Riggins, 2007). It thus seems that several mid-latitude sites were characterized by a stronger seasonality during the PETM.

\section{Conclusions}

Several conclusions can be drawn from this work on the organic record of PaleoceneEocene boundary terrestrial/lagoonal sediments at Vasterival (Upper-Normandy, France).

1. Carbon-isotope ratios of vascular plant biomarkers show a CIE extending to the lagoonal SAOM Member, thicker than the one inferred from the bulk $\mathrm{OM} \delta^{13} \mathrm{C}$. This difference is explained by the mixing of OM from different sources, which may be the cause of the zigzag 
shape of several sections in Northwestern Europe where successions of terrestrial and lagoonal deposits are also observed.

2. Palynofacies observations reveal a change in the environment concomitant with the onset of the CIE: the closed marsh environment of the latest Paleocene being replaced by an open eutrophic swamp characterized by algal blooms during the earliest Eocene. This swamp was then progressively drowned by the marine transgression.

3. Hydrogen-isotope ratios of vascular plant biomarkers reveal that the latest Paleocene was subjected to major climatic fluctuations, such as a dry phase that occurred just prior to the CIE onset. This episode recorded in other sections around the world suggests that a global climatic change occurred just before the PETM, which may indicate that a strong volcanic episode is involved in a series of events that led to the triggering of the PETM.

4. The comparison of the hydrogen isotope data to that of the nitrogen isotope of organic matter reveals that the Cap d'Ailly area underwent moister conditions along with a stronger seasonality during the lowermost PETM.

\section{Acknowledgments}

This paper is a contribution to the Research cooperation contract financially supported by the BRGM ("Paléosurface éocène-PETM" research project), to the FRFC-FNRS grant no 2.4571.10. Emile Roche (Liège University) is acknowledged for scientific discussion. We thank Florence Savignac, Frédéric Delbes and Jamel Benmamar (Paris 6 University) and Marielle Hatton (Orléans University) for their technical support. We would also like to thank P. Meyers and one anonymous reviewer for their constructive comments and Kyle Taylor for his helpful remarks and comments. Finally, we thanks Elizabeth Rowley-Jolivet for English revision. 


\section{References}

Amundson, R., Austin, A.T., Schuur, E.A.G., Yoo, K., Matzek, V., Kendall, C., Uebersax, A., Brenner, D., Baisden, W.T., 2003. Global patterns of the isotopic composition of soil and plant nitrogen. Global Biogeochem. Cycles 17, 10 PP.

Aranibar, J.N., Otter, L., Macko, S.A., Feral, C.J.W., Epstein, H.E., Dowty, P.R., Eckardt, F., Shugart, H.H., Swap, R.J., 2004. Nitrogen cycling in the soil-plant system along a precipitation gradient in the Kalahari sands. Global Change Biology 10, 359-373.

Aubry, M.-P., Ouda, K., Dupuis, C., Berggren, W.A., Van Couvering, J.A., Ali, J., Brinkhuis, H., Gingerich, P.R., Heilmann-Clausen, C., Hooker, J., Kent, D.V., King, C., Knox, R.W.O.B., Laga, P., Molina, E., Schmitz, B., Steurbaut, E., Ward, D.R., 2007. The Global Standard Stratotype-section and Point (GSSP) for the base of the Eocene Series in the Dababiya section (Egypt). Episodes 30, 271-286.

Aubry, M.-P., Thiry, M., Dupuis, C., Berggren, W.A., 2005. The Sparnacian deposits of the Paris Basin: A lithostratigraphic classification. Stratigraphy 2, 65-100.

Austin, A.T., Vitousek, P.M., 1998. Nutrient dynamics on a precipitation gradient in Hawai'i. Oecologia 113, 519-529.

Aziz, H.A., Hilgen, F.J., Van Luijk, G.M., Sluijs, A., Kraus, M.J., Pares, J.M., Gingerich, P.D., 2008. Astronomical climate control on paleosol stacking patterns in the upper Paleocene-lower Eocene Willwood Formation, Bighorn Basin, Wyoming. Geology 36, $531-534$.

Bains, S., Norris, R.D., Corfield, R.M., Bowen, G.J., Gingerich, P.D., Koch, P.L., 2003. Marine terrestrial linkages at the Paleocene-Eocene boundary, in Wing, S.L., et al., (Editors), Causes and consequences of globally warm climates in the early Paleogene: Geological Society of America Special Paper 369, p. 1-9.

Batten, D.J., 1996. Chapter 26A. Palynofacies and paleoenvironmental interpretation, in: Jansonius, J. \& McGregor, D.C. (Editors), Palynology: Principles and Applications, American Association of Stratigraphic Palynologists Foundation. pp. 1011-1064. 
Behar, F., Beaumont, V., Penteado, H.L De B., 2001, Rock-Eval 6 Technology:

Performances and Developments. Revue de l'Institut Français du Pétrole 56, 111134.

Bennett, A.J.R., 1964. Origin and formation of coal seams. Coal Research in C.S.I.R.O. 22, $9-18$.

Bignot, G., 1965. Le gisement éocène du Cap d'Ailly (près de Dieppe Seine-Maritime). Bulletin de la Société Géologique de France 7, 273-283.

Bignot, G., 1984. Le calcrète de la base des faciès sparnaciens de la région de Reims est également présent au Cap d'Ailly (76-Haute Normandie). Bulletin d'Information des Géologues du Bassin de Paris 21, 3-8.

Bossard, N., Jacob, J., Le Milbeau, C., Lallier-Vergès, E., Terwilliger, V.J., Boscardin, R., 2011. Variation in $\delta D$ values of a single, species-specific molecular biomarker: a study of miliacin throughout a field of broomcorn millet (Panicum miliaceum L.). Rapid Communications in Mass Spectrometry 25, 2732-2740.

Bowen, G.J., Revenaugh, J., 2003. Interpolating the isotopic composition of modern meteoric precipitation. Water Resour. Res. 39, 13 PP.

Bray, E.E., Evans, E.D., 1961. Distribution of n-paraffins as a clue to recognition of source beds. Geochimica et Cosmochimica Acta 22, 2-15.

Breyer, J.A., 1984. Tide-dominated delta model for coal-bearing Wilcox strata in south Texas. American Association of Petroleum Geologists Bulletin 68, 457-484.

Bujak, J.P., Brinkhuis, H., 1998. Global warming and dinocyst changes across the Paleocene/Eocene boundary. In: Aubry, M.-P., et al. (Editors) Late Paleocene - Early Eocene Climatic and Biotic events in the marine and terrestrial records. Columbia University Press, New York Chapter 14, 277-295.

Burky, A.J., 1983. Physiological Ecology of Freshwater Bivalves, in: Russell-Hunter (ed.) The Mollusca Ecology. New York. 
Carvajal-Ortiz, H., Mora, G., Jaramillo, C., 2009. A molecular evaluation of bulk organic carbon-isotope chemostratigraphy for terrestrial correlations: An example from two Paleocene-Eocene tropical sequences. Palaeogeography, Palaeoclimatology, Palaeoecology 277, 173-183.

Cavagnetto, C., 2000. La palynoflore d'un gisement d'ambre de l'Eocène basal du Bassin Parisien(Le Quesnoy, France). Palaeontographica Abteilung B 255, 147-171.

Cerling, T.E., 1984. The stable isotopic composition of modern soil carbonate and its relationship to climate. Earth and Planetary Science Letters 71, 229-240.

Cerling, T.E., Quade, J., 1993. Stable carbon and oxygen isotopes in soil carbonates. in Climate Change in Continental Isotopic Records, Geophysical Monograph Series 78, PP. 217-231.

Chaffee, A.L., Hoover, D.S., Johns, R.B., Schweighardt, F.K., 1986. Biological markers extractable from coal, in: R.B. Johns, Editor, Biological Markers in the Sedimentary Record. Amsterdam, pp. 311-347.

Chikaraishi, Y., Naraoka, H., 2003. Compound-specific $\delta D-\delta 13 C$ analyses of n-alkanes extracted from terrestrial and aquatic plants. Phytochemistry 63, 361-371.

Chikaraishi, Y., Naraoka, H., 2007. $\delta 13 C$ and $\delta D$ relationships among three n-alkyl compound classes (n-alkanoic acid, n-alkane and n-alkanol) of terrestrial higher plants. Organic Geochemistry 38, 198-215.

Cline, J.D., Kaplan, I.R., 1975. Isotopic fractionation of dissolved nitrate during denitrification in the eastern tropical north pacific ocean. Marine Chemistry 3, 271-299.

Cohen, A.D., 1970. An Allochthonous Peat Deposit from Southern Florida. Geological Society of America Bulletin 81, 2477 -2482.

Coleman, M., Raiswell, R., 1981. Carbon, oxygen and sulphur isotope variations in concretions from the Upper Lias of N.E. England. Geochimica et Cosmochimica Acta 45, 329-340. 
Collinson, M.E., Steart, D.C., Harrington, G.J., Hooker, J.J., Scott, A.C., Allen, L.O., Glasspool, I.J., Gibbons, S.J., 2009. Palynological evidence of vegetation dynamics in response to palaeoenvironmental change across the onset of the PaleoceneEocene Thermal Maximum at Cobham, Southern England. Grana 48, 38-66.

Collinson, M.E., Steart, D.C., Scott, A.C., Glasspool, I.J., Hooker, J.J., 2007. Episodic fire, runoff and deposition at the Paleocene-Eocene boundary. Journal of the Geological Society $164,87$.

Crouch, E.M., Dickens, G.R., Brinkhuis, H., Aubry, M.-P., Hollis, C.J., Rogers, K.M., Visscher, H., 2003. The Apectodinium acme and terrestrial discharge during the Paleocene-Eocene thermal maximum: new palynological, geochemical and calcareous nannoplankton observations at Tawanui, New Zealand. Palaeogeography, Palaeoclimatology, Palaeoecology 194, 387-403.

Dansgaard, W., 1964. Stable isotopes in precipitation. Tellus 16, 436-468.

Dickens, G.R., Castillo, M.M., Walker, J.C.G., 1997. A blast of gas in the latest Paleocene: Simulating first-order effects of massive dissociation of oceanic methane hydrate. Geology 25, 259.

Dickens, G.R., Oneil, J., Rea, D., Owen, R., 1995. Dissociation of oceanic methane hydrate as a cause of the carbon-isotope excursion at the end of the Paleocene. Paleoceanography 10, 965-971.

Diefendorf, A.F., Mueller, K.E., Wing, S.L., Koch, P.L., Freeman, K.H., 2010. Global patterns in leaf $13 \mathrm{C}$ discrimination and implications for studies of past and future climate. Proceedings of the National Academy of Sciences 107, 5738 -5743.

Diessel, C.F.K., 1992. Coal-bearing depositional systems. Springer-Verlag, Berlin. Dupuis, C., Steurbaut, E., 1987. Altérites, sables marins (NP8, NP9) et fluviatiles, silicification et stromatolites dans le Paléocène supérieur entre Criel et le Cap d'Ailly (Haute-Normandie). Annales de la société géologique du Nord CV, 233-242. 
Dupuis, C., Steurbaut, E., De Coninck, J., Riveline, J., 1998. The Western Argiles à Lignites facies. In: M. Thiry and C. Dupuis (Eds.), The Paleocene/Eocene boundary in Paris basin: the Sparnacian deposits. Field trip guide. ENSMP Mém. Sc. De la Terre, 34, $60-71$.

Eglinton, G., Gonzalez, A.G., Hamilton, R.J., Raphael, R.A., 1962. Hydrocarbon constituents of the wax coatings of plant leaves: A taxonomic survey. Phytochemistry 1, 89-102.

Eglinton, G., Hamilton, R.J., 1967. Leaf Epicuticular Waxes. Science 156, 1322-1335.

Epstein, S., Yapp, C.J., 1976. Climatic implications of the D/H ratio of hydrogen in $\mathrm{C}-\mathrm{H}$ groups in tree cellulose. Earth and Planetary Science Letters 30, 252-261.

Espitalié, J., Deroo, G., Marquis, F., 1985a. La pyrolyse Rock-Eval et ses applications, première partie. Revue de l'Institut Français du Pétrole 40, 563-579.

Espitalié, J., Deroo, G., Marquis, F., 1985b. La pyrolyse Rock-Eval et ses applications, deuxième partie. Revue de l'Institut Français du Pétrole 40, 755-784.

Feakins, S.J., Sessions, A.L., 2010. Controls on the D/H ratios of plant leaf waxes in an arid ecosystem. Geochimica et Cosmochimica Acta 74, 2128-2141.

Ficken, K.J., Li, B., Swain, D.L., Eglinton, G., 2000. An n-alkane proxy for the sedimentary input of submerged/floating freshwater aquatic macrophytes. Organic Geochemistry $31,745-749$.

Foreman, B.Z., Heller, P.L., Clementz, M.T., 2012. Fluvial response to abrupt global warming at the Palaeocene/Eocene boundary. Nature 491, 92-95.

Gavrilov, Y.O., Kodina, L.A., Lubchenko, I.Y. \& Muzylev, N.G., 1997: The late Paleocene anoxic event in epicontinental seas of Peri-Tethys and formation of the sapropelite unit; sedimentology and geochemistry. Lithology and Mineral Resources 32, 427-450

Gingerich, P.D., 2006. Environment and evolution through the Paleocene-Eocene thermal maximum. Trends in Ecology \& Evolution 21, 246-253. 
Gingerich, P.D., 1989. New earliest Wasatchian mammalian fauna from the Eocene of northwestern Wyoming: composition and diversity in a rarely sampled high-floodplain assemblage. Museum of Paleontology, University of Michigan.

Good, S.C., 2004. Paleoenvironmental and paleoclimatic significance of freshwater bivalves in the Upper Jurassic Morrison Formation, Western Interior, USA. Sedimentary Geology 167, 163-176.

Guy-Ohlson, D., 1996. Chapter 7B. Prasinophycean algae., in: Jansonius, J.; McGregor, D.C. (ed.). Palynology: Principles and Applications., American Association of Stratigraphic Palynologists Foundation. pp. 181-189.

Handley, L.L., Austin, A.T., Stewart, G.R., Robinson, D., Scrimgeour, C.M., Raven, J.A., Heaton, T.H.E., Schmidt, S., 1999. The $15 \mathrm{~N}$ natural abundance $(\delta 15 \mathrm{~N})$ of ecosystem samples reflects measures of water availability. Functional Plant Biol. 26, 185-199.

Handley, L., Crouch, E.M., Pancost, R.D., 2011. A New Zealand record of sea level rise and environmental change during the Paleocene-Eocene Thermal Maximum.

Palaeogeography, Palaeoclimatology, Palaeoecology 305, 185-200.

Handley, L., O’Halloran, A., Pearson, P.N., Hawkins, E., Nicholas, C.J., Schouten, S., McMillan, I.K., Pancost, R.D., 2012. Changes in the hydrological cycle in tropical East Africa during the Paleocene-Eocene Thermal Maximum. Palaeogeography, Palaeoclimatology, Palaeoecology 329-330, 10-21.

Higgins, J.A., Schrag, D.P., 2006. Beyond methane: Towards a theory for the PaleoceneEocene Thermal Maximum. Earth and Planetary Science Letters 245, 523-537. Jacob, J., Disnar, J.-R., Boussafir, M., Ledru, M.-P., Spadano Albuquerque, A.L., Sifeddine, A., Turcq, B., 2004. Onocerane attests to dry climatic events during the Quaternary in the tropics. Organic Geochemistry 35, 289-297.

Jacob, J., Disnar, J.-R., Boussafir, M., Spadano Albuquerque, A.L., Sifeddine, A., Turcq, B., 2005. Pentacyclic triterpene methyl ethers in recent lacustrine sediments (Lagoa do Caço, Brazil). Organic Geochemistry 36, 449-461. 
John, C.M., Banerjee, N.R., Longstaffe, F.J., Sica, C., Law, K.R., Zachos, J.C., 2012. Clay assemblage and oxygen isotopic constraints on the weathering response to the Paleocene-Eocene thermal maximum, east coast of North America. Geology 40, $591-594$.

Karamanos, R.E., Voroney, R.P., Rennie, D.A., 1981. Variation in Natural N-15 Abundance of Central Saskatchewan Soils. Soil Science Society of America Journal 45, 826-828.

Kennett, J., Stott, L., 1991. Abrupt deep-sea warming, palaeoceanographic changes and benthic extinctions at the end of the Paleocene. Nature 353, 225-229.

Kimble, B.J., Maxwell, J.R., Philp, R.P., Eglinton, G., 1974. Identification of steranes and tritepanes in geolipid extracts by high-resolution gas chromatography and mass spectrometry. Chemical Geology 14, 173-198.

Koch, P.L., Zachos, J.C., Gingerich, P.D., 1992. Correlation between isotope records in marine and continental carbon reservoirs near the Palaeocene/Eocene boundary. Nature 358, 319-322.

Kramer, M.G., Sollins, P., Sletten, R.S., Swart, P.K., 2003. N Isotope Fractionation and Measures of Organic Matter Alteration during Decomposition. Ecology 84, 20212025 .

Kraus, M.J., Riggins, S., 2007. Transient drying during the Paleocene-Eocene Thermal Maximum (PETM): Analysis of paleosols in the bighorn basin, Wyoming. Palaeogeography, Palaeoclimatology, Palaeoecology 245, 444-461.

Lavrieux, M., Jacob, J., LeMilbeau, C., Zocatelli, R., Masuda, K., Bréheret, J.-G., Disnar, J.R., 2011. Occurrence of triterpenyl acetates in soil and their potential as chemotaxonomical markers of Asteraceae. Organic Geochemistry 42, 1315-1323.

Leavitt, S.W., Newberry, T., 1992. Systematics of stable-carbon isotopic differences between gymnosperm and angiosperm trees. Plant Physiology (Life Science Advances) 11, 257-262. 
Liu, W., Wang, Z., 2008. Nitrogen isotopic composition of plant-soil in the Loess Plateau and its responding to environmental change. Chinese Science Bulletin 54, 272-279.

Liu, X., Wang, G., 2010. Measurements of nitrogen isotope composition of plants and surface soils along the altitudinal transect of the eastern slope of Mount Gongga in southwest China. Rapid Communications in Mass Spectrometry 24, 3063-3071.

Magioncalda, R., Dupuis, C., Blamart, D., Fairon-Demaret, M., Perreau, M., Renard, M., Riveline, J., Roche, M., Keppens, E., 2001. L'excursion isotopique du carbone organique (delta $13 \mathrm{C}$ org ) dans les paleoenvironnements continentaux de l'intervalle Paleocene/Eocene de Varangeville (Haute-Normandie). Bulletin de la Societe Geologique de France 172, 349 -358.

Magioncalda, R., Dupuis, C., Smith, T., Steurbaut, E., Gingerich, P.D., 2004. PaleoceneEocene carbon isotope excursion in organic carbon and pedogenic carbonate: Direct comparison in a continental stratigraphic section. Geology 32, 553.

Mclnerney, F.A., Wing, S.L., 2011. The Paleocene-Eocene Thermal Maximum: A Perturbation of Carbon Cycle, Climate, and Biosphere with Implications for the Future. Annual Review of Earth and Planetary Sciences 39, 489-516.

Meyers, P.A., 1997. Organic geochemical proxies of paleoceanographic, paleolimnologic, and paleoclimatic processes. Organic Geochemistry 27, 213-250.

Moore, E.A., Kurtz, A.C., 2008. Black carbon in Paleocene-Eocene boundary sediments: A test of biomass combustion as the PETM trigger. Palaeogeography, Palaeoclimatology, Palaeoecology 267, 147-152.

Murphy, B.H., Farley, K.A., Zachos, J.C., 2010. An extraterrestrial 3He-based timescale for the Paleocene-Eocene thermal maximum (PETM) from Walvis Ridge, IODP Site 1266. Geochimica et Cosmochimica Acta 74, 5098-5108.

Nielsen, H., Sørensen, I., 1992. Taxonomy and stratigraphy of late-glacial Pediastrum taxa from Lysmosen, Denmark - a preliminary study. Review of Palaeobotany and Palynology 74, 55-75. 
Pacton, M., Gorin, G.E., Vasconcelos, C., 2011. Amorphous organic matter - Experimental data on formation and the role of microbes. Review of Palaeobotany and Palynology 166, 253-267.

Pagani, M., Pedentchouk, N., Huber, M., Sluijs, A., Schouten, S., Brinkhuis, H., Sinninghe Damsté, J.S., Dickens, G.R., Expedition 302 Scientists, Backman, J., Clemens, S., Cronin, T., Eynaud, F., Gattacceca, J., Jakobsson, M., Jordan, R., Kaminski, M., King, J., Koc, N., Martinez, N.C., Mclnroy, D., Moore Jr, T.C., O’Regan, M., Onodera, J., Pälike, H., Rea, B., Rio, D., Sakamoto, T., Smith, D.C., St John, K.E.K., Suto, I., Suzuki, N., Takahashi, K., Watanabe, M., Yamamoto, M., 2006. Arctic hydrology during global warming at the Palaeocene/Eocene thermal maximum. Nature 442, $671-675$.

Pearson, M.J., Obaje, N.G., 1999. Onocerane and other triterpenoids in Late Cretaceous sediments from the Upper Benue Trough, Nigeria: tectonic and palaeoenvironmental implications. Organic Geochemistry 30, 583-592.

Pelet, R., 1985. Sédimentation et évolution géologique de la matière organique. Bulletin de la Société Géologique de France 8, 1075-1086.

Peters, K., Walters, C., Moldowan, M., 2005. The biomarker guide, Cambridge university press. ed. New York.

Raiswell, R., 1988. Chemical model for the origin of minor limestone-shale cycles by anaerobic methane oxidation. Geology 16, $641-644$.

Retallack, G.J., 2005. Pedogenic carbonate proxies for amount and seasonality of precipitation in paleosols. Geology 33, 333.

Röhl, U., Westerhold, T., Bralower, T.J., Zachos, J.C., 2007. On the duration of the Paleocene-Eocene thermal maximum (PETM). Geochem. Geophys. Geosyst. 8, Q12002.

Rommerskirchen, F., Eglinton, G., Dupont, L., Güntner, U., Wenzel, C., Rullkötter, J., 2003. A north to south transect of Holocene southeast Atlantic continental margin 
sediments: Relationship between aerosol transport and compound-specific $\delta^{13} \mathrm{C}$ land plant biomarker and pollen records. Geochem. Geophys. Geosyst. 4, 1101.

Sachse, D., Billault, I., Bowen, G.J., Chikaraishi, Y., Dawson, T.E., Feakins, S.J., Freeman, K.H., Magill, C.R., Mclnerney, F.A., van der Meer, M.T.J., Polissar, P., Robins, R.J., Sachs, J.P., Schmidt, H.-L., Sessions, A.L., White, J.W.C., West, J.B., Kahmen, A., 2012. Molecular Paleohydrology: Interpreting the Hydrogen-Isotopic Composition of Lipid Biomarkers from Photosynthesizing Organisms. Annual Review of Earth and Planetary Sciences 40, 221-249.

Sachse, D., Kahmen, A., Gleixner, G., 2009. Significant seasonal variation in the hydrogen isotopic composition of leaf-wax lipids for two deciduous tree ecosystems (Fagus sylvativa and Acer pseudoplatanus). Organic Geochemistry 40, 732-742.

Sachse, D., Radke, J., Gleixner, G., 2004. Hydrogen isotope ratios of recent lacustrine sedimentary n-alkanes record modern climate variability. Geochimica et Cosmochimica Acta 68, 4877-4889.

Sarmaja-Korjonen, K., Seppänen, A., Bennike, O., 2006. Pediastrum algae from the classic late glacial Bølling Slo site, Denmark: response of aquatic biota to climate change. Review of Palaeobotany and Palynology 138, 95-107.

Sass, E., Bein, A., Almogi-Labin, A., 1991. Oxygen-isotope composition of diagenetic calcite in organic-rich rocks: Evidence for 180 depletion in marine anaerobic pore water. Geology 19, 839-842.

Sauer, P.E., Eglinton, T.I., Hayes, J.M., Schimmelmann, A., Sessions, A.L., 2001. Compound-specific $\mathrm{D} / \mathrm{H}$ ratios of lipid biomarkers from sediments as a proxy for environmental and climatic conditions1. Geochimica et Cosmochimica Acta 65, 213222.

Schmitz, B., Pujalte, V., 2003. Sea-level, humidity, and land-erosion records across the initial Eocene thermal maximum from a continental-marine transect in northern Spain. Geology 31, 689. 
Schmitz, B., Pujalte, V., 2007. Abrupt increase in seasonal extreme precipitation at the Paleocene-Eocene boundary. Geology 35, 215 -218.

Schobert, H.H., 1995. Lignites of North America, Elsevier Scientific Publishing Co. ed. Amsterdam.

Schouten, S., Woltering, M., Rijpstra, W.I.C., Sluijs, A., Brinkhuis, H., Sinninghe Damsté, J.S., 2007. The Paleocene-Eocene carbon isotope excursion in higher plant organic matter: Differential fractionation of angiosperms and conifers in the Arctic. Earth and Planetary Science Letters 258, 581-592.

Schwark, L., Zink, K., Lechterbeck, J., 2002. Reconstruction of postglacial to early Holocene vegetation history in terrestrial Central Europe via cuticular lipid biomarkers and pollen records from lake sediments. Geology 30, $463-466$.

Secord, R., Gingerich, P.D., Lohmann, K.C., MacLeod, K.G., 2010. Continental warming preceding the Palaeocene-Eocene thermal maximum. Nature 467, 955-958.

Shearer, G., Kohl, D., 1986. N2-Fixation in Field Settings: Estimations Based on Natural 15N Abundance. Functional Plant Biol. 13, 699-756.

Shearer, G. \& Kohl, D.H. (1988) 15N method of estimating N2 fixation. In: Stable Isotopes in Ecological Research - Rundel, Ehleringer andNagy (ed.), pp. 342-374. SpringerVerlag, New York.

Shearer, G. \& Kohl, D.H. (1993) Natural abundance of 15N: fractional contribution of two sources to a common sink and use of isotope discrimination. In: Nitrogen Isotope Techniques - Knowles and Blackburn (ed.), pp. 89.

Sinha, A., 1997. Systematics of carbon isotopic exchange among the ocean, atmosphere, and terrestrial biosphere: implications for global stratigraphic correlations. $\mathrm{PhD}$ thesis, U.S.C University of Southern California, $211 \mathrm{pp}$.

Sluijs, A., Schouten, S., Pagani, M., Woltering, M., Brinkhuis, H., Damsté, J.S.S., Dickens, G.R., Huber, M., Reichart, G.-J., Stein, R., Matthiessen, J., Lourens, L.J., Pedentchouk, N., Backman, J., Moran, K., the Expedition 302 Scientists, 2006. 
Subtropical Arctic Ocean temperatures during the Palaeocene/Eocene thermal maximum. Nature 441, 610-613.

Sluijs, A., Brinkhuis H., Schouten S., Bohaty S.M., John C.M., Zachos J.C., Reichart G.-J., Sinninghe Damste J.S., Crouch E.M., Dickens G.R., 2007. Environmental precursors to rapid light carbon injection at the Palaeocene/Eocene boundary, Nature 450, 12181222.Smith, F.A., Freeman, K.H., 2006. Influence of physiology and climate on [delta]D of leaf wax n-alkanes from C3 and C4 grasses. Geochimica et Cosmochimica Acta 70, 1172-1187.

Smith, F.A., Freeman, K.H., 2006. Influence of physiology and climate on $\delta D$ of leaf wax nalkanes from C3 and C4 grasses. Geochimica et Cosmochimica Acta 70, 1172-1187.

Smith, F.A., Wing, S.L., Freeman, K.H., 2007. Magnitude of the carbon isotope excursion at the Paleocene-Eocene thermal maximum: The role of plant community change. Earth and Planetary Science Letters 262, 50-65.

Smith, J.J., Hasiotis, S.T., Kraus, M.J., Woody, D.T., 2008. Naktodemasis Bowni: New Ichnogenus and Ichnospecies for Adhesive Meniscate Burrows (AMB), and Paleoenvironmental Implications, Paleogene Willwood Formation, Bighorn Basin, Wyoming. Journal of Paleontology 82, 267-278.

Smith, T., Dupuis, C., Folie, A., Quesnel, F., Storme, J.-Y., lacumin, P., Riveline, J., Missiaen, P., Ladevèze, S., Yans, J., 2011. A new terrestrial vertebrate site just after the Paleocene-Eocene boundary in the Mortemer Formation of Upper Normandy, France. Comptes Rendus Palevol 10, 11-20.

Smith, T., Rose, K.D., Gingerich, P.D., 2006. Rapid Asia-Europe-North America geographic dispersal of earliest Eocene primate Teilhardina during the Paleocene-Eocene thermal maximum. Proceedings of the National Academy of Sciences 103, 11223.

Stefanova, M., Magnier, C., Velinova, D., 1995. Biomarker assemblage of some Mioceneaged Bulgarian lignite lithotypes. Organic Geochemistry 23, 1067-1084. 
Steurbaut, E., Magioncalda, R., Dupuis, C., van Simaeys, S., Roche, E., Roche, M., 2003. Palynology, paleoenvironments, and organic carbon isotope evolution in lagoonal Paleocene-Eocene boundary settings in North Belgium. Geological Society of America Special Papers 369, 291-317.

Storme, J.-Y., Devlesschouwer, X., Schnyder, J., Cambier, G., Baceta, J.I., Pujalte, V., Di Matteo, A., lacumin, P., Yans, J., 2012a. The Palaeocene/Eocene boundary section at Zumaia (Basque-Cantabric Basin) revisited: new insights from high resolution magnetic susceptibility and carbon isotope chemostratigraphy on organic matter (ס13Corg). Terra Nova 24, 310-317.

Storme, J.-Y., Dupuis, C., Schnyder, J., Quesnel, F., Garel, S., lakovleva, A.I., Iacumin, P., Di Matteo, A., Sebilo, M., Yans, J., 2012b. Cycles of humid-dry climate conditions around the P/E boundary: new stable isotope data from terrestrial organic matter in Vasterival section (NW France). Terra Nova 24, 114-122.

Svensen, H., Planke, S., Corfu, F., 2010. Zircon dating ties NE Atlantic sill emplacement to initial Eocene global warming. Journal of the Geological Society 167, 433-436.

Svensen, H., Planke, S., Malthe-Sørenssen, A., Jamtveit, B., Myklebust, R., Rasmussen Eidem, T., Rey, S.S., 2004. Release of methane from a volcanic basin as a mechanism for initial Eocene global warming. Nature 429, 542-545.

Swap, R.J., Annegarn, H.J., Suttles, J.T., King, M.D., Platnick, S., Privette, J.L., Scholes, R.J., 2003. Africa burning: A thematic analysis of the Southern African Regional Science Initiative (SAFARI 2000). J. Geophys. Res. 108, 8465.

Thiry, M., Aubry, M.-P., Dupuis, C., Sinha, A., Stott, L.D., Berggren, W.A., 2006. The Sparnacian deposits of the Paris Basin: d13C Isotope stratigraphy. Stratigraphy 3, $119-138$.

Thiry, M., Dupuis, C., 1998. Chemostratigraphy of the Sparnacian deposits and correlation to deep-sea record. In : The Paleocene/Eocene boundary in Paris basin : the 
Sparnacian deposits. Field trip guide - Thiry et Dupuis (ed.), E. N. S. M. P. Mèm. Sc. de la Terre 34, 39-47.

Tipple, B.J., Pagani, M., Krishnan, S., Dirghangi, S.S., Galeotti, S., Agnini, C., Giusberti, L., Rio, D., 2011. Coupled high-resolution marine and terrestrial records of carbon and hydrologic cycles variations during the Paleocene-Eocene Thermal Maximum (PETM). Earth and Planetary Science Letters 311, 82-92.

Tyson, R.V., 1995. Sedimentary Organic Matter. Organic Facies and Palynofacies, Chapman and Hall.

Van Dongen, B.E., Talbot, H.M., Schouten, S., Pearson, P.N., Pancost, R.D., 2006. Well preserved Palaeogene and Cretaceous biomarkers from the Kilwa area, Tanzania. Organic Geochemistry 37, 539-557.

Visser, J.M., Sasser, C.E., 2009. The effect of environmental factors on floating fresh marsh end-of-season biomass. Aquatic Botany 91, 205-212.

Westerhold, T., Röhl, U., Raffi, I., Fornaciari, E., Monechi, S., Reale, V., Bowles, J., Evans, H.F., 2008. Astronomical calibration of the Paleocene time. Palaeogeography, Palaeoclimatology, Palaeoecology 257, 377-403.

Whelan, T., Roberts, H.H., 1973. Carbon isotope composition of diagenetic carbonate nodules from freshwater swamp sediments. Journal of sedimentary research $43,54-$ 58.

Wing, S.L., Harrington, G.J., Smith, F.A., Bloch, J.I., Boyer, D.M., Freeman, K.H., 2005. Transient Floral Change and Rapid Global Warming at the Paleocene-Eocene Boundary. Science, New Series 310, 993-996.

Yans, J., Strait, S.G., Smith, T., Dupuis, C., Steurbaut, E., Gingerich, P.D., 2006. Highresolution carbon isotope stratigraphy and mammalian faunal change at the Paleocene-Eocene boundary in the Honeycombs area of the southern Bighorn Basin, Wyoming. American journal of science 306, 712. 
Zachos, J., Pagani, M., Sloan, L., Thomas, E., Billups, K., 2001. Trends, Rhythms, and Aberrations in Global Climate 65 Ma to Present. Science, New Series 292, 686-693. Zachos, J.C., Röhl, U., Schellenberg, S.A., Sluijs, A., Hodell, D.A., Kelly, D.C., Thomas, E., Nicolo, M., Raffi, I., Lourens, L.J., McCarren, H., Kroon, D., 2005. Rapid Acidification of the Ocean during the Paleocene-Eocene Thermal Maximum. Science, New Series $308,1611-1615$

Zachos, J.C., Wara, M.W., Bohaty, S., Delaney, M.L., Petrizzo, M.R., Brill, A., Bralower, T.J., Premoli-Silva, I., 2003. A Transient Rise in Tropical Sea Surface Temperature during the Paleocene-Eocene Thermal Maximum. Science, New Series 302, 1551-1554. 


\section{Figure captions}

Figure 1: Location of Vasterival and Cap d'Ailly Area (Dupuis et al., 1998, modified).

Figure 2: Lithostratigraphy and paleoenvironments of the composite section of the "Côte d'Albâtre" (Cap d'Ailly, Dieppe and Criel sections) that encompasses the uppermost Paleocene and the lowermost Eocene. $\mathrm{K}^{*}$ : Late Cretaceous; SAAC: "Sables et Argiles à Annélides de Caude-Côte"; SP: Sparnacian; SAOM: "Sables et Argiles à Ostracodes et Mollusques"; CRA: "Craquelins"; NP: Nannofossil Zones ; terr.: terrestrial (modified after Magioncalda et al., 2001; Aubry et al., 2005 and Storme et al., 2012b).

Figure 3: Vasterival section lithological log, sampling, bulk $\delta^{13}$ Corg curve, interval of Apectodinium occurrence and interval of Apectodinium acme. $\mathrm{CIE}=$ Carbon Isotope Excursion (Storme et al., 2012b, modified)

Figure 4: Palynofacies main categories: (A) gelified amorphous organic matter (gAOM), gelified phytoclast (GP) and pollen (P); (B) fluorescent organic matter under UV; (C) area of diffuse amorphous organic matter (dAOM), gelified phytoclast (GP) and pyrite framboids (py); (D) large flakes of gelified organic matter and gelified phytoclasts; (E) a dinoflagellate cyst of Apectodinium homomorphum under UV; (F) a Pediastrum algae under UV

Figure 5: Vasterival samples plotted in a HI (Hydrogen Index) / OI (Oxygen Index) diagram.

Type I: lacustrine; Type II: marine; Type III: continental

Figure 6 : Vasterival relative abundances of gelified AOM, gelified phytoclasts, Fluorescent AOM, diffuse AOM, Botryococcus spp., Pediastrum spp., spore and pollen grains, and 
dinoflagellate cysts (this work) in comparison with lithology (same legend as in Fig. 3) and bulk $\delta^{13} \mathrm{C}_{\text {org }}$ curve (Storme et al., 2012b)

Figure 7: Stratigraphic variability of the $n$-alkane Carbon Preference Index (CPI; Bray and Evans, 1961), $n$-alkane aquatic/terrestrial plant ratio $\left(P_{\text {aq }}\right.$; Ficken et al., 2000), relative concentrations of $\mathrm{C}_{27}, \mathrm{C}_{29}$ and $\mathrm{C}_{31} n$-alkanes (this work), in comparison with lithology (same legend as in Fig. 3) and bulk $\delta^{13} \mathrm{C}$ curve (Storme et al., 2012b) in the Vasterival section.

Figure 8: $n$-alkane $\delta^{13} \mathrm{C}$ and $n$-alkane and onocerane I $\delta \mathrm{D}$ (this work) in comparison with lithology (same legend as in Fig. 3) and bulk $\delta^{13} \mathrm{C}_{\text {org }}$ curve (Storme et al., 2012b) in the Vasterival section. The error bars in the $n$-alkane isotopic records correspond to the standard deviation based on duplicate $\left(\delta^{13} \mathrm{C}\right)$ and triplicate $(\delta \mathrm{D})$ analyses.

Figure 9: $C_{27} n$-alkane $\delta^{13} \mathrm{C}$ and $\delta \mathrm{D}$; relative abundances of Fluorescent $A O M$, Pediastrum spp. and dinoflagellate cysts (this work), in comparison with lithology (same legend as in Fig. 3), $\delta^{15} \mathrm{~N}_{\text {org }}$ evolution (Storme et al., 2012b) and paleoenvironments in the Vasterival section. 


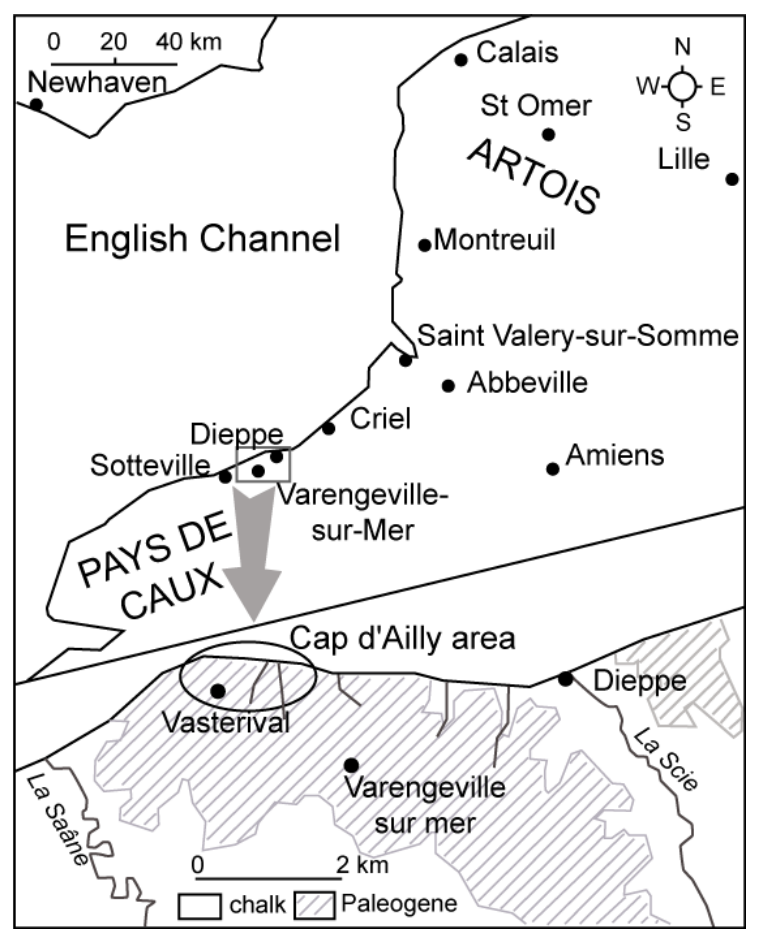

Figure 7 


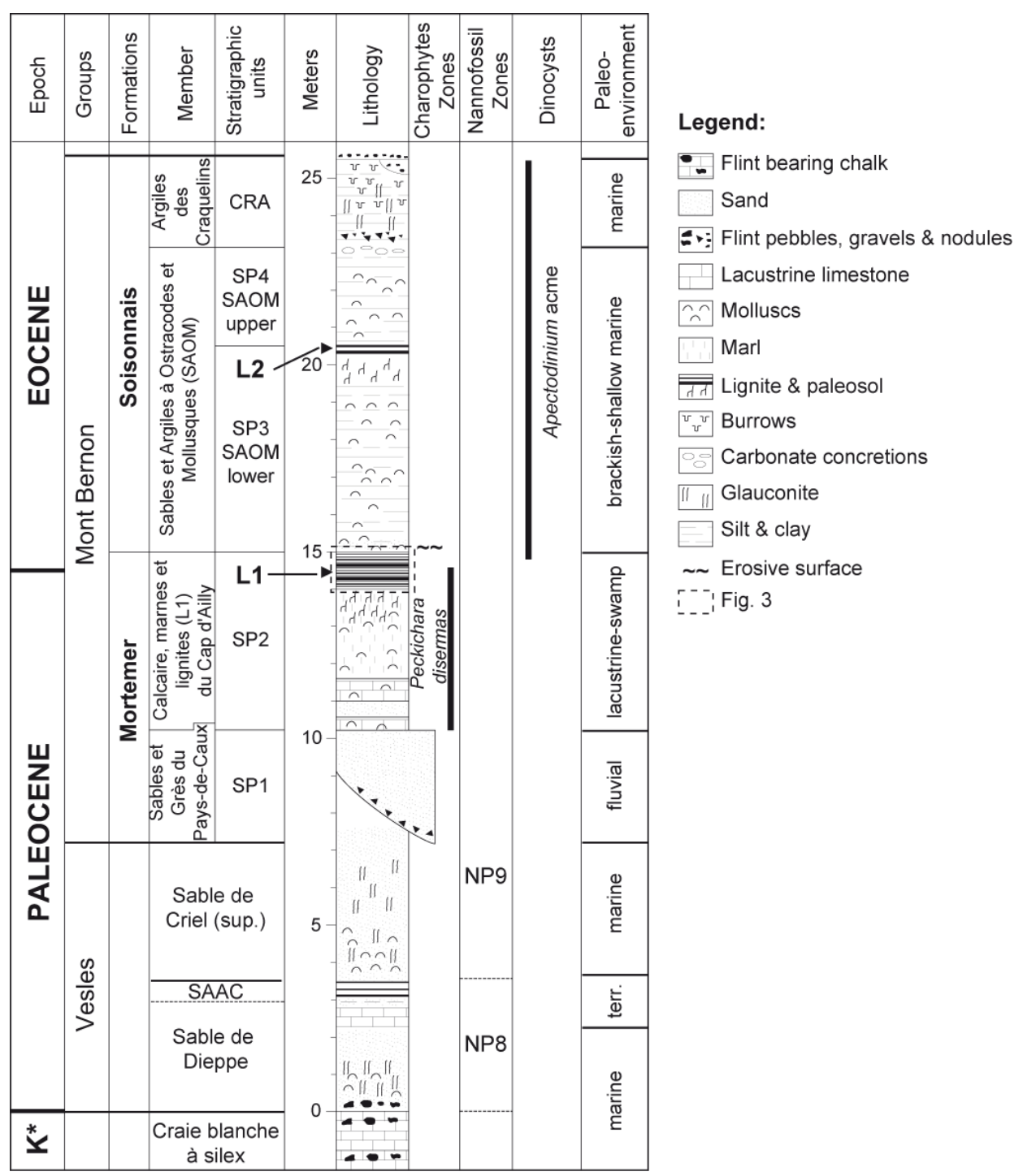

Figure 2 


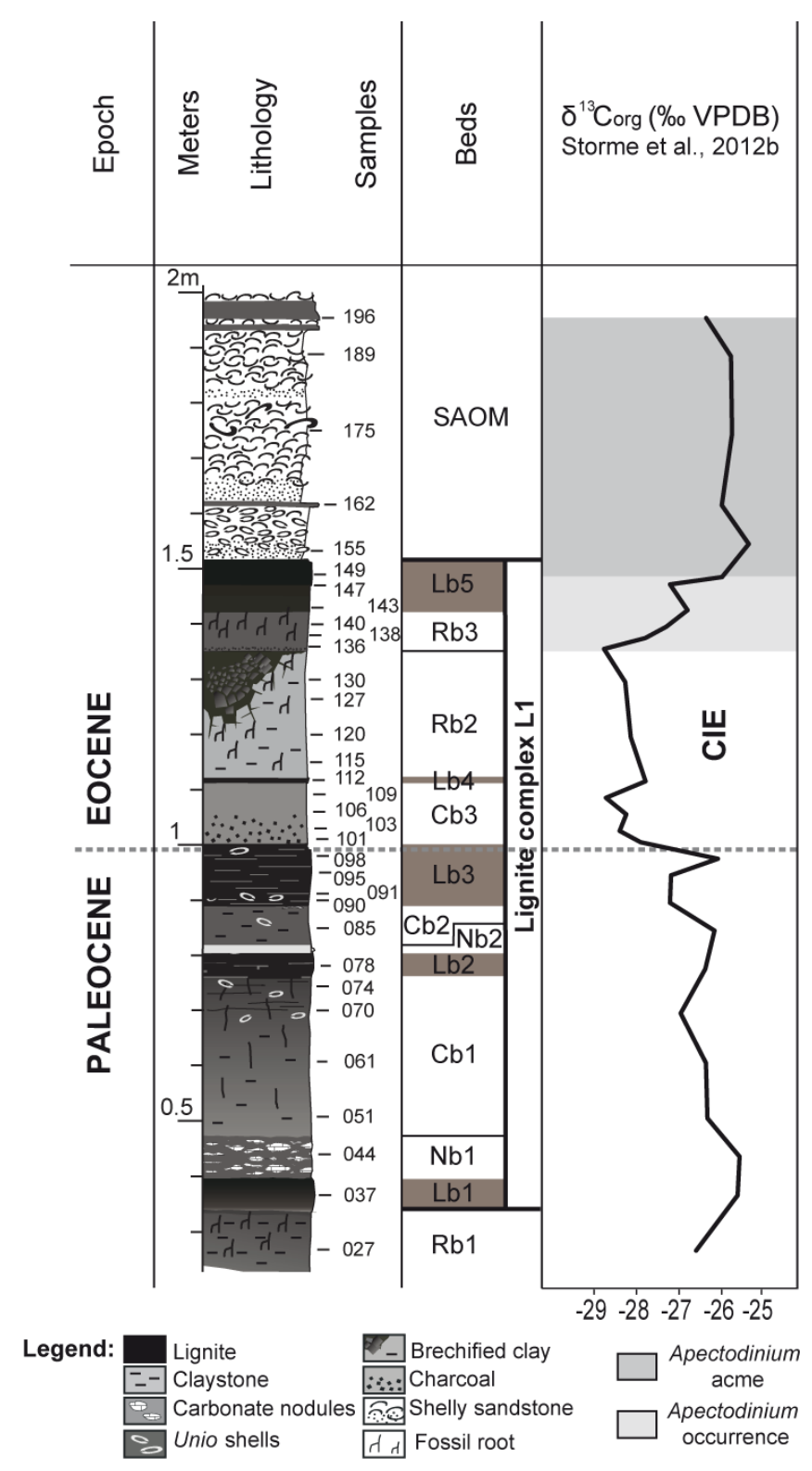

Figure 3 

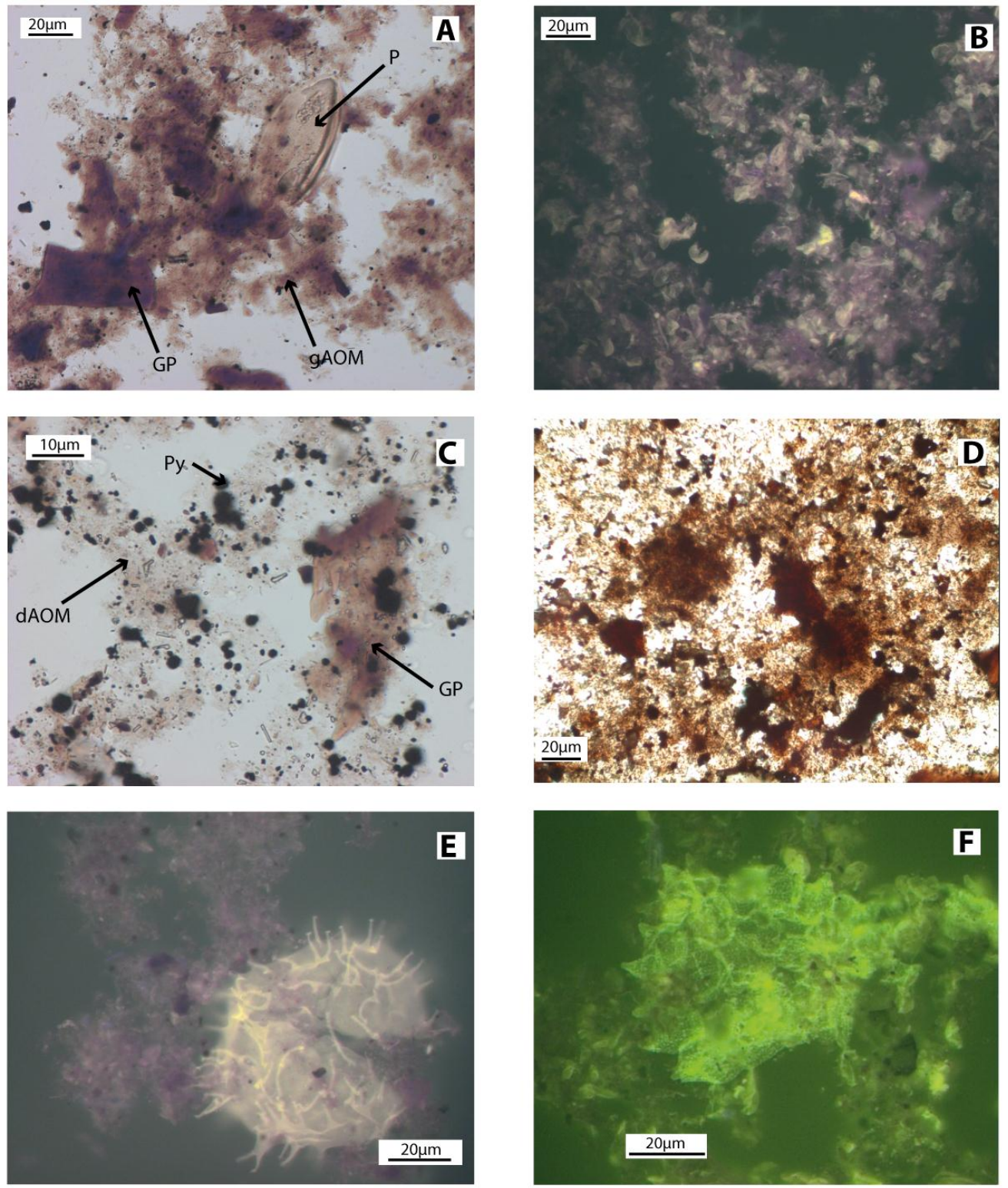

Figure 4 


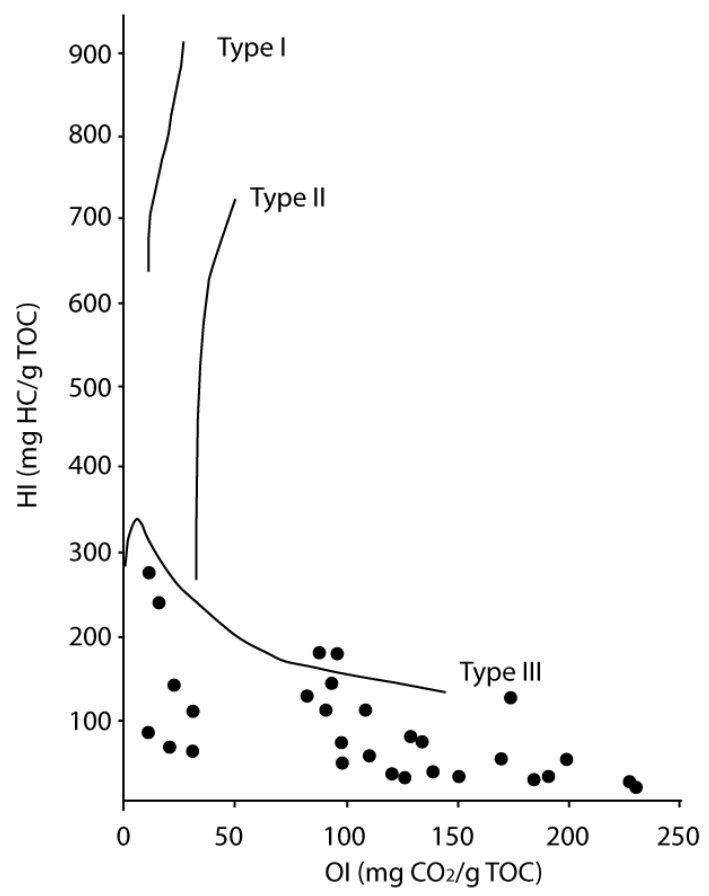

Figure 5 


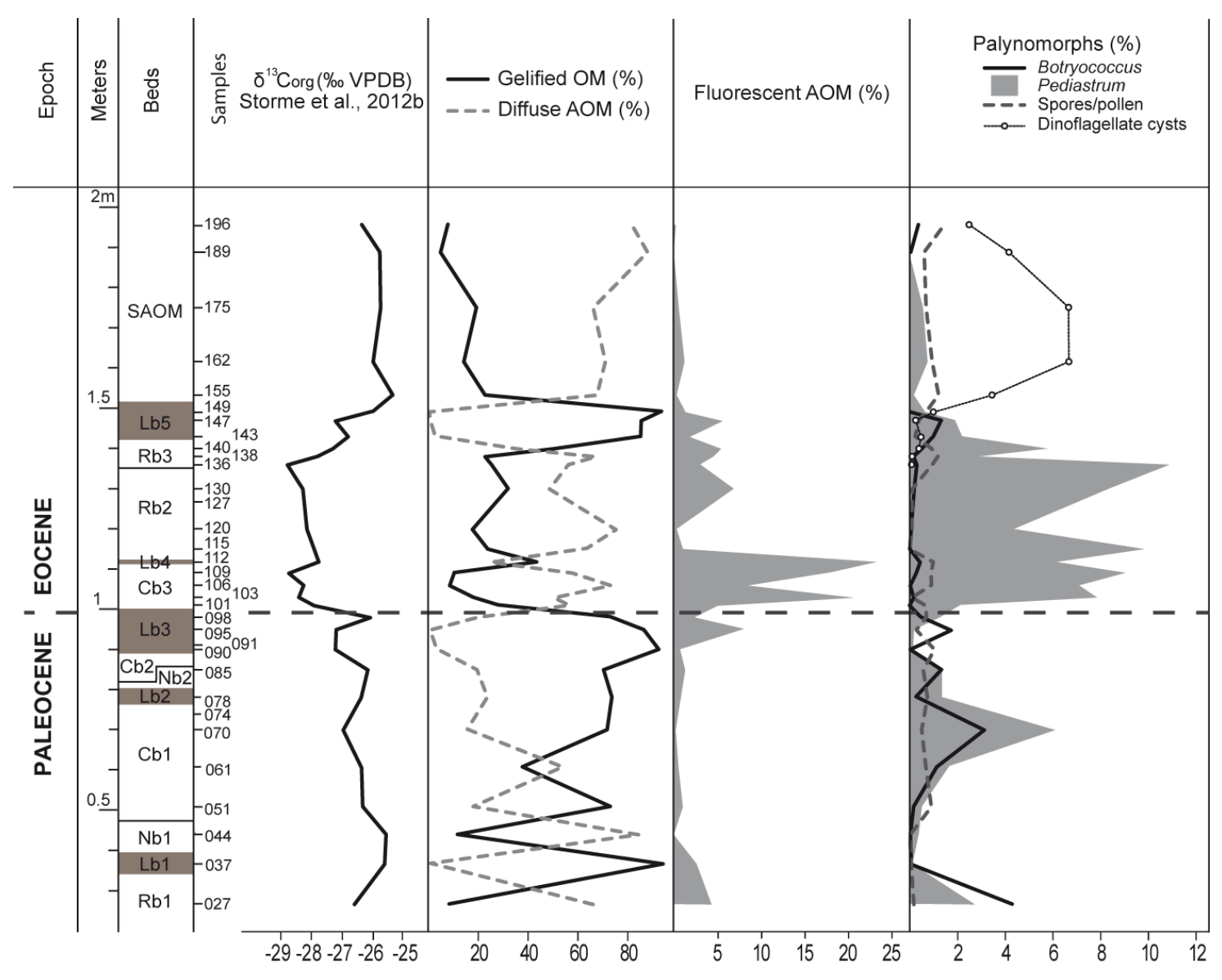

Figure 6 


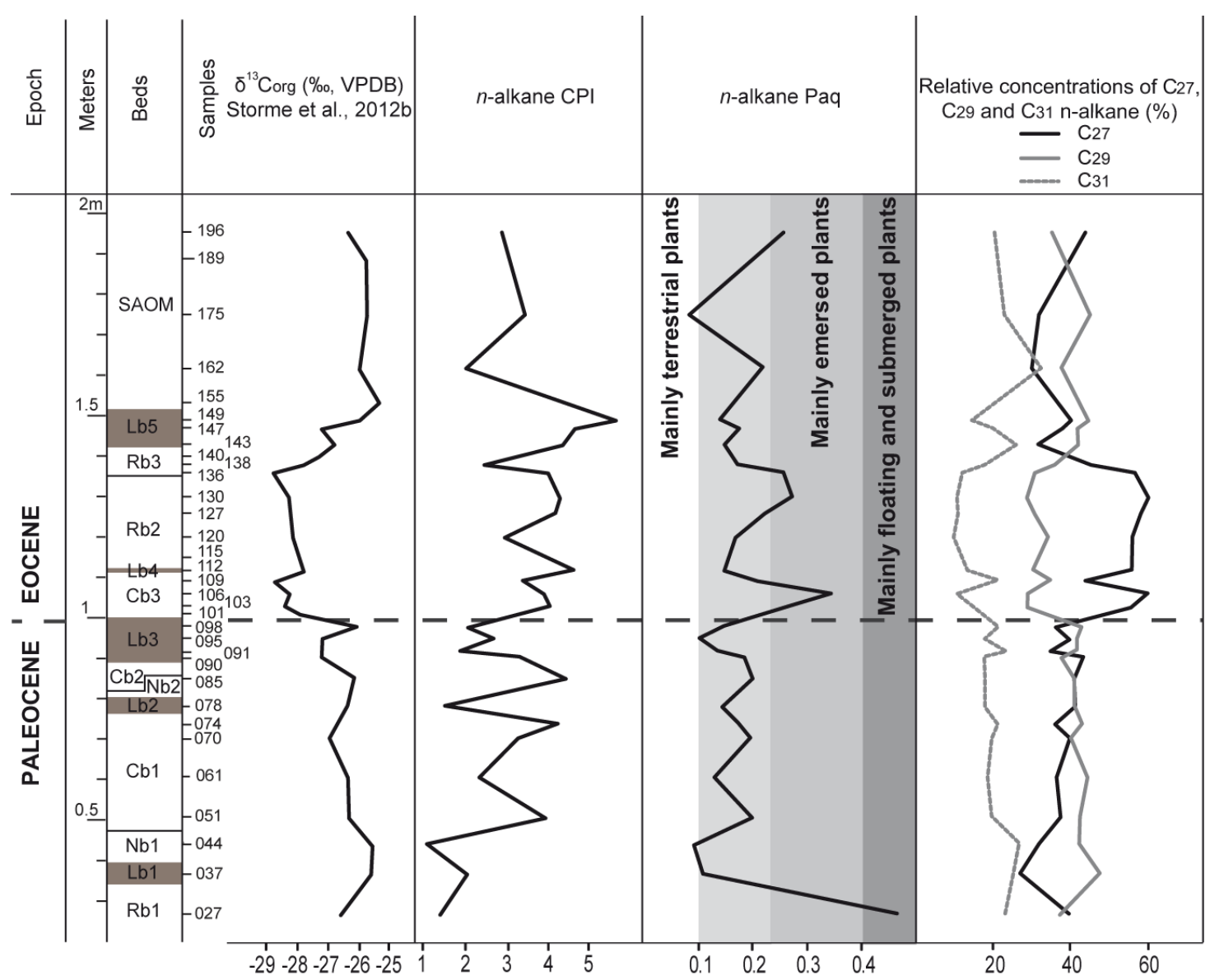

Figure 7 


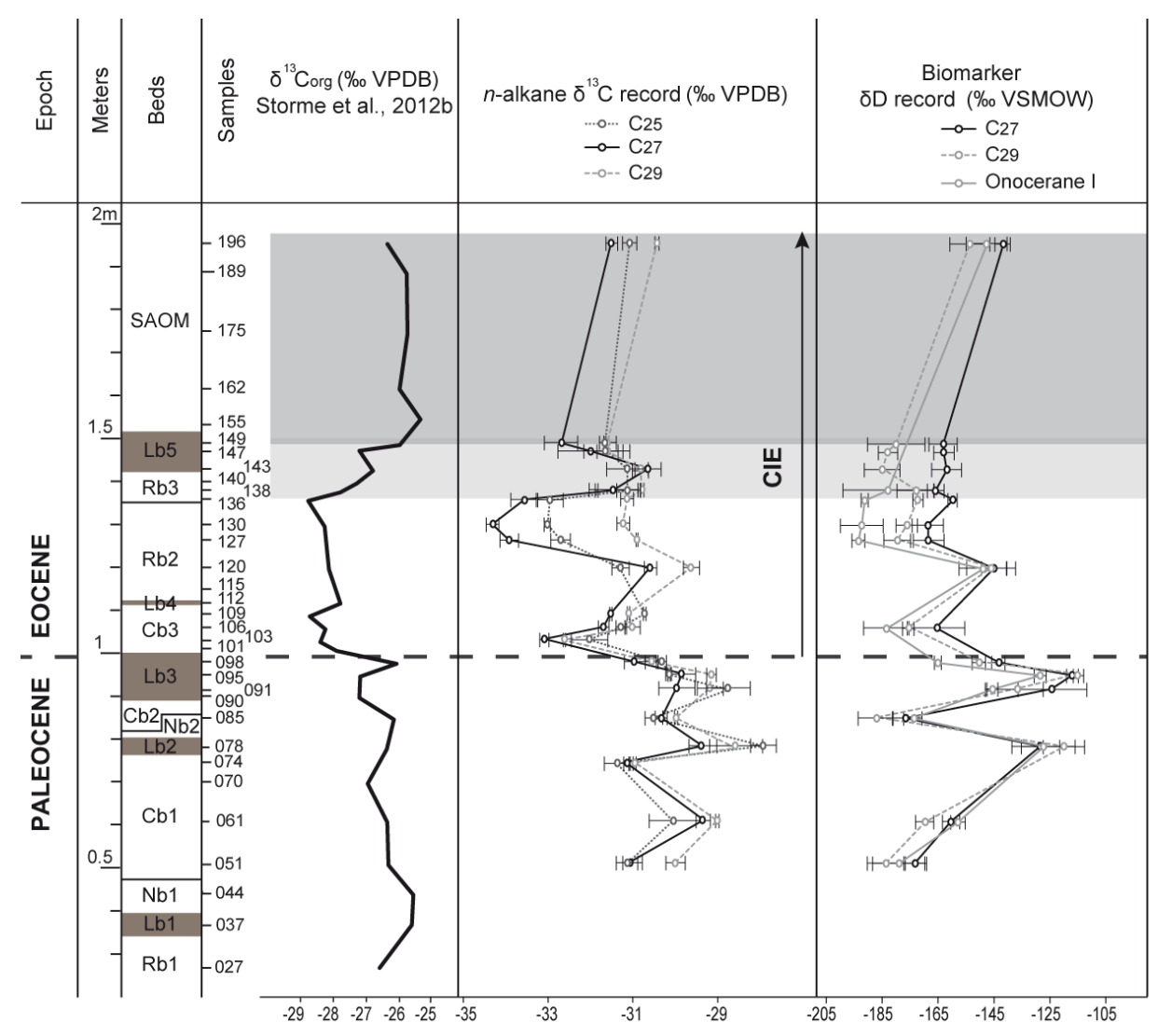

Figure 8 


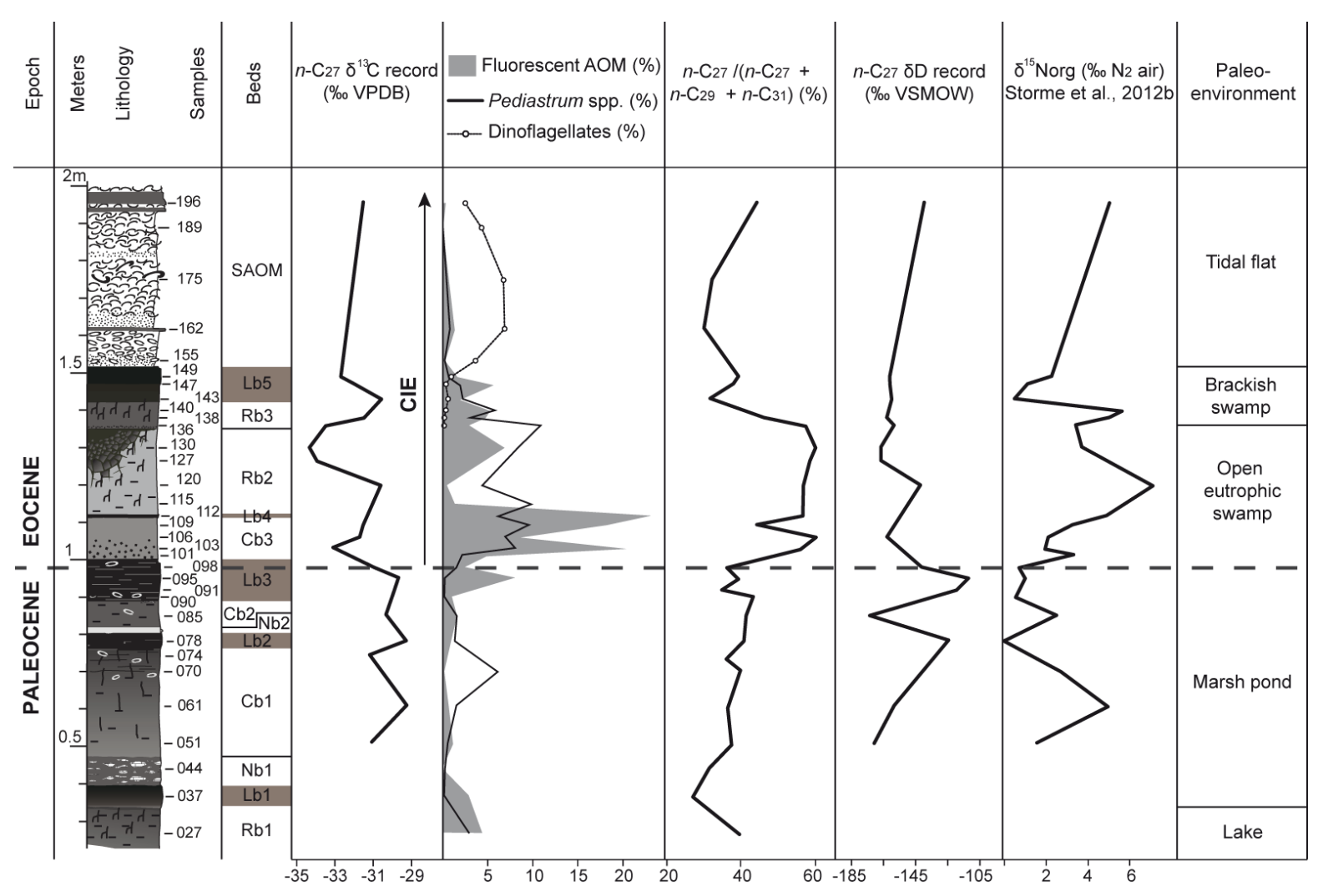

Figure 9 